University of New Hampshire

University of New Hampshire Scholars' Repository

Law Faculty Scholarship

University of New Hampshire - Franklin Pierce

School of Law

3-1-2016

\title{
The Riddle of Harmless Error Revisited
}

John M. Greabe

University of New Hampshire School of Law, john.greabe@law.unh.edu

Follow this and additional works at: https://scholars.unh.edu/law_facpub

Part of the Constitutional Law Commons, Criminal Procedure Commons, and the Legal Remedies Commons

\section{Recommended Citation}

John M. Greabe, The Riddle of Harmless Error Revisited, 54 Hous. L. Rev, 59 (2016).

This Article is brought to you for free and open access by the University of New Hampshire - Franklin Pierce School of Law at University of New Hampshire Scholars' Repository. It has been accepted for inclusion in Law Faculty Scholarship by an authorized administrator of University of New Hampshire Scholars' Repository. For more information, please contact sue.zago@law.unh.edu. 


\title{
ARTICLE
}

\section{THE RIDDLE OF HARMLESS ERROR REVISITED}

\author{
John M. Greabe*
}

\begin{abstract}
Half a century ago, in Chapman v. California, the Supreme Court imposed on appellate courts an obligation to vacate or reverse criminal judgments marred by constitutional error unless the government demonstrates that the error was harmless beyond a reasonable doubt. But the Court did not explain the juridical status of this obligation or its relation to the federal harmless-error statute, 28 U.S.C. $§ 2111$. In the intervening years, commentators have struggled to make sense of Chapman. Some see it as a constitutional mandate. Others view it as an example of constitutional common law. In The Riddle of Harmless Error, written shortly after Chapman issued, Justice Roger Traynor argued that $\S 2111$ should govern the field that Chapman occupies.

The lack of clarity about Chapman's pedigree has had the predictable consequence of leaving harmless-error doctrine in an unsatisfactory state. Most basically, the Court has adopted a harmless-error test that unduly privileges constitutional error vis-à-vis nonconstitutional error. Moreover, the Court has prescribed application of an easily manipulated jurisprudence of labels to determine whether an error is amenable to harmless-error review. Finally, the Court has unnecessarily

* Professor, University of New Hampshire School of Law. Thanks to Seth Aframe, Michael Coenen, Toby Heytens, Hon. Jeffrey Howard, Mary Leary, Hon. Landya McCafferty, Leah Plunkett, Anne Poulin, and Richard Re for reading and commenting on this paper. Thanks also to Chloe Golden, Tom Hemstock, Brooke Lovett Shilo, and the editors of the Houston Law Review for research and editorial assistance. Finally, thanks to the University of New Hampshire School of Law for a summer research stipend to support this project.
\end{abstract}


complicated the application of harmless-error analysis on collateral review and, along the way, shown insufficient regard for rule-of-law values.

This Article takes a fresh look at what the Constitution requires of reviewing courts when they conclude that a criminal judgment has been tainted by constitutional error. It suggests that new insights may be found by situating harmless-error doctrine within a broader, transcontextual analysis of how constitutional remedies function. It then demonstrates how understanding what the Constitution requires of reviewing courts can serve as a springboard for necessary reform. Ultimately, it argues that the Supreme Court can and should jettison Chapman in favor of a simplified, unitary, and transcontextual harmless-error test-reconceived as an elaboration of 28 U.S.C. $\S 2111$ - that largely tracks the approach for which Justice Traynor argued. Under this test, a reviewing court would set aside any conviction tainted by error unless it concludes that it was highly probable that the error did not affect the judgment. A reviewing court also would set aside any conviction tainted by error if the error undermined fundamental constitutional values.

TABLE OF CONTENTS

I. INTRODUCTION

II. The BAsics of HARMLESS-ERRor REview: Evolution, ONTOLOGY \& CONSTITUTIONAL OBLIGATION...........................65

A. A Brief History .........................................................66

1. Harmless Error on Direct Review ..........................66

2. Harmless Error on Collateral Review ....................76

3. Summary ........................................................... 78

B. The Ontology of Chapman \& Its Progeny ...................... 79

C. Constitutional Obligation: A Working Hypothesis \& Response to Professor Re ........................................ 86

III. Assessing THE STATUS QUO: A NEED FOR REFORM.............. 95

A. The "Privileging" of Constitutional Error ...................... 96

B. The Structural Defect/Trial Error Dichotomy.............101

C. Recent Habeas Cases...................................................... 109 
IV. SUGGESTED REFORMS

A. The Constitution \& the Path to Reform ....................... 115

B. A Unitary Standard (and Abandoning Chapman) ...... 115

C. Abandoning Fulminante........................................... 119

D. Abandoning Brecht................................................ 121

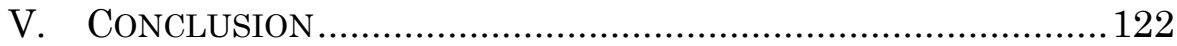

\section{INTRODUCTION}

It has been nearly half a century since Justice Roger J. Traynor published The Riddle of Harmless Error. ${ }^{1}$ The book was a response to many of the questions raised and left unanswered by the Supreme Court's then-recent decision in Chapman $v$. California. $^{2}$ Chapman is the source of two important, interrelated precepts that inform the work of federal and state appellate courts on a daily basis. First, a court conducting direct review of a criminal conviction is not under an unyielding duty to vacate or reverse when a trial judge or prosecutor has committed a federal constitutional violation during the judicial proceedings that led to the conviction. ${ }^{3}$ But second, the court must set the conviction aside if the government fails to establish that the error was "harmless beyond a reasonable doubt." ${ }^{4}$ My concern is with the second holding - that reviewing courts must provide remedies for errors not shown to have been harmless beyond a reasonable doubt. I will refer to this holding as the "Chapman principle."

The juridical status of the Chapman principle is an enigma, despite the efforts of Traynor and others to shine an illuminating light upon it. Although Chapman states that the principle derives from federal law, ${ }^{5}$ the Supreme Court has never specified its precise source. Is it a constitutional mandate rooted in underlying constitutional criminal trial rights or the obligation of

1. Roger J. Traynor, The Riddle of Harmless Error (1970). As Traynor recognized, harmless-error doctrines apply in both the criminal and civil contexts. See, e.g., id. at 16-17, 48-49. For the most part, however, Traynor focused on the criminal side, where harmless-error standards have received far more attention and proven to be far more controversial. I too will confine my focus to harmless-error review on direct and collateral review of criminal convictions.

2. 386 U.S. 18, 22-24 (1967).

3. Id. at $21-22$.

4. Id. at 24 .

5. The Court stated: "Whether a conviction for a crime should stand when a State has failed to accord federal constitutionally guaranteed rights is every bit as much of a federal question as what particular constitutional provisions themselves mean, what they guarantee, and whether they have been denied.” Id. at 21. 
appellate courts to provide due process? Several commentators have characterized it in this way. $^{6}$ Alternatively, is it a subconstitutional rule that serves as an example of what Professor Henry P. Monaghan calls "constitutional common law"?7 Professor Daniel J. Meltzer and others have so described it. ${ }^{8}$ And what is its relation to 28 U.S.C. $\S 2111$, a federal statute that directs reviewing courts to withhold remedies for all errors that have not affected the substantial rights of the parties? ${ }^{9}$ Traynor thought that $\S 2111$ should govern the field that Chapman occupies, and he proposed that the Court treat future harmless-error decisions as elaborations of the statute. ${ }^{10}$

The lack of clarity about Chapman's pedigree has had the predictable consequence of leaving harmless-error doctrine in an unsatisfactory state. Most basically, the Supreme Court has never offered a coherent defense of its practice of "privileging" constitutional errors: i.e., insisting that constitutional errors merit a remedy unless shown to have been harmless "beyond a reasonable doubt," while requiring that nonconstitutional errors be evaluated under a more forgiving standard. ${ }^{11}$ Moreover, the

6. See Richard M. Re, The Due Process Exclusionary Rule, 127 HARV. L. REV. 1885, 1912-18 (2014) (suggesting that harmless-error analysis be constitutionalized and rooted in the Constitution's due process guarantee); Stephen H. Goldberg, Harmless Error: Constitutional Sneak Thief, 71 J. CRIM. L. \& CRIMINOLOGY 421, 424 n.31 (1980) (characterizing the Chapman principle as a "constitutional judgment").

7. Henry P. Monaghan, The Supreme Court, 1974 Term, Foreword: Constitutional Common Law, 89 HARV. L. Rev. 1, 19 (1975) [hereinafter Monaghan, Constitutional Common Law]; see also Henry P. Monaghan, Harmless Error and the Valid Rule Requirement, 1989 S. СT. REv. 195, 200 n.30 (describing Chapman as an example of constitutional common law). Monaghan defines constitutional common law as "a substructure of substantive, procedural, and remedial rules drawing their inspiration and authority from, but not required by, various constitutional provisions." Monaghan, Constitutional Common Law at 2-3.

8. See, e.g., Daniel J. Meltzer, Harmless Error and Constitutional Remedies, 61 U. CHI. L. REv. 1, 26-29 (1994); Craig Goldblatt, Comment, Harmless Error as Constitutional Common Law: Congress's Power to Reverse Arizona v. Fulminante, 60 U. CHI. L. REv. 985, 1009-12 (1993). I too have subscribed to this description of Chapman. See John M. Greabe, Remedial Discretion in Constitutional Adjudication, 62 BUfF. L. REV. 881, 920 \& n.197 (2014).

9. 28 U.S.C. $\S 2111$ (2012) states: "On the hearing of any appeal or writ of certiorari in any case, the court shall give judgment after an examination of the record without regard to errors or defects which do not affect the substantial rights of the parties." The statute is operationalized in the federal courts through FED. R. CRIM. P. 52(a) and FED. R. CIV. P. 61, both of which instruct courts to withhold remedies for errors that did not affect the substantial rights of a party.

10. See TRAYNOR, supra note 1 , at 42 .

11. See Michael Coenen, Constitutional Privileging, 99 VA. L. REV. 683, 695-97 (2013) (explaining that, while constitutional errors amenable to harmless-error review must be shown on direct appeal to have been harmless beyond a reasonable doubt (per Chapman), nonconstitutional errors are subject to a "more forgiving standard" and may be disregarded where there is "fair assurance ... that the judgment was not substantially 
Court's most important "clarification" of Chapman, provided in Arizona v. Fulminante in 1991,12 has caused more problems than it has solved. In Fulminante, the Court held that courts conducting direct review of convictions should always provide remedies for "structural defects,"13 but should conduct harmless-error review of all "trial errors." 14 Yet the Court has operationalized the Fulminante framework in unprincipled and unpredictable ways. ${ }^{15}$ Finally, on collateral review, the Court continues to require application of a confusing, more-forgiving-than-Chapman harmless-error test-a practice begun in Brecht $v$. Abrahamson in 199316_even though subsequently enacted limitations on the availability of collateral relief in the Antiterrorism and Effective Death Penalty Act of 1996 ("AEDPA") are more than sufficient to protect federalism values and address other concerns raised by habeas-based reversals. ${ }^{17}$

swayed by the error") (quoting Kotteakos v. United States, 328 U.S. 750, 765 (1946)).

12. 499 U.S. 279, 306-09 (1991).

13. Id. at 309 (defining "structural defects" as "defects in the constitution of the trial mechanism, which defy analysis by harmless-error standards") (internal quotation marks omitted).

14. Id. at 307-08 (defining "trial errors" as "error[s] which occur[ during the presentation of the case to the jury, and which may therefore be quantitatively assessed in the context of other evidence presented in order to determine whether [their] admission was harmless").

15. For a sampling of the commentary critical of Fulminante, see Roger A. Fairfax, Jr., Harmless Constitutional Error and the Institutional Significance of the Jury, 76 FoRDHAM L. REV. 2027, 2038-40 (2008) (arguing that the Court is undermining the institutional significance of the jury by holding, subsequent to Fulminante, that instructional errors that preclude the jury from returning a verdict on all elements of the charged offense are nonstructural); David McCord, The "Trial/Structural" Error Dichotomy: Erroneous, and Not Harmless, 45 U. KAN. L. REV. 1401, 1414 (1997) (arguing that the structural error/trial error framework is inherently flawed and has proved to be unworkable); Charles J. Ogletree, Jr., Comment, Arizona v. Fulminante: The Harm of Applying Harmless Error to Coerced Confessions, 105 HARV. L. REV. 152, 154 (1991) (criticizing the single-minded focus on the accuracy of convictions inherent in the trial error/structural defect dichotomy); see also, e.g., Michael Coenen, Spillover Across Remedies, 98 MiNN. L. REV. 1211, 1235-39 (2014) (noting that the Fulminante framework can cause courts to define structural rights too narrowly in order to avoid the strong medicine of automatic reversal); Daryl J. Levinson, Rights Essentialism and Remedial Equilibration, 99 Colum. L. REv. 857, 891-92 (1999) (similar); Steven M. Shephard, Note, The Case Against Automatic Reversal of Structural Errors, 117 YALE L. J. 1180, 1185-86, 1201 (2008) (similar, arguing against a rule of automatic reversal of structural errors); Pamela S. Karlan, Race, Rights, and Remedies in Criminal Adjudication, 96 MicH. L. REV. 2001, 2021 (1998) (similar, discussing the equal protection right protected by Batson v. Kentucky, 476 U.S. 79 (1986)).

16. See 507 U.S. 619, 623 (1993).

17. The limiting principles in question are found in 28 U.S.C. $\S 2254$ (d) (2012), which provides:

An application for a writ of habeas corpus on behalf of a person in custody pursuant to the judgment of a State court shall not be granted with respect to 
In short, the riddle of harmless error is ripe for revisiting. This paper undertakes the task. Part I provides essential background about the development of the harmless-error doctrine and the range of views about its essential nature. It then demonstrates the possibility of a conceptual breakthrough by supplementing the debate over ontology (what is the Chapman principle?) with an analysis of remedial function (how does the setting aside of a criminal conviction serve as a remedy for a constitutional violation at trial?). A functional approach proves useful because it helps to define the border between constitutionally compelled and constitutionally gratuitous remedies. Generally speaking, the Constitution requires courts to provide specific remedies responsive to ongoing constitutional violations, but permits courts to weigh the costs and benefits of substitutionary remedies for wholly concluded constitutional wrongs and to withhold such remedies if their costs would be too great.

This functional insight leads to the paper's foundational hypothesis: while reviewing courts must remedy an ongoing infringement of constitutional rights worked by conviction under a facially unconstitutional statute or a statute that cannot be constitutionally applied on the facts of the case, the Supreme Court and Congress are otherwise free to craft harmless-error doctrines that reflect the lessons of experience. This freedom flows from the fact that, once we set to the side the exception involving conviction pursuant to an unconstitutional or unconstitutionally applied statute, an order vacating or reversing a tainted judgment provides substitutionary relief for a wholly concluded wrong; it does not deliver a constitutionally compelled remedy.

Part II turns to the current state of harmless-error doctrine and argues that it is unsatisfactory. It exposes three principal problems. First, the Supreme Court has adopted a harmless-error framework that unduly privileges constitutional error vis-à-vis nonconstitutional error. Second, the Court has prescribed application of a flawed, easily manipulated jurisprudence of labels to determine whether an error is amenable to harmless-error review. Third, the Court has unnecessarily complicated the application of harmless-error

any claim that was adjudicated on the merits in State court proceedings unless the adjudication of the claim-(1) resulted in a decision that was contrary to, or involved an unreasonable application of, clearly established Federal law, as determined by the Supreme Court of the United States; or (2) resulted in a decision that was based on an unreasonable determination of the facts in light of the evidence presented in the State court proceeding. 
analysis on collateral review and, along the way, shown an insufficient regard for rule-of-law values.

Part III begins by observing that, with clarity about how little the Constitution requires with respect to harmless-error review, the path is open to reforms that could ameliorate each of the problems described in Part II. It then argues that the Supreme Court should jettison the Chapman principle and abandon the structural defect/trial error dichotomy in favor of a simplified, unitary, and transcontextual harmless-error testreconceived as an elaboration of 28 U.S.C. $§ 2111$ - that tracks the approach for which Traynor argued in The Riddle of Harmless Error. Under this approach, the Court should instruct reviewing courts to set aside a judgment tainted by any error (whether constitutional or not) unless they conclude that it was highly probable that the error did not affect the judgment.

Beyond this, the Court should emphasize that, even when guilty of the crimes charged, appellants and petitioners pressing claims of constitutional error serve as private attorneys general and therefore function as essential instruments for ensuring proper regard for fundamental constitutional values. Accordingly, the Court should authorize reviewing courts to exercise their power to set aside judgments tainted by error in circumstances where, regardless of whether it is highly probable that the error affected the judgment, an exercise of remedial discretion is necessary to vindicate such values. Such circumstances certainly include errors that undermine the rights to an impartial judge, a jury instruction that correctly states the relevant standard of proof, the assistance of counsel for the accused, and a fair jury. They also should include, but are not necessarily limited to, judicial proceedings marred by unconstitutional discrimination on the basis of race, religion, ethnicity, national origin, or gender and intentional misconduct by government officials such as judges, prosecutors, and police or probation officers.

\section{THE BASICS OF HARMLESS-ERROR REVIEW: EVOLUTION, ONTOLOGY \& CONSTITUTIONAL OBLIGATION}

A sound solution to a legal problem-indeed, a sound solution to most any problem-typically requires an understanding of how the problem came to be and the context within which it arises. So it is with harmless-error review. The path towards improvement opens upon a close analysis of the doctrine's origins and nature, the role it plays within the field of remedies, and the constitutional constraints within which it 
operates. This Part supplies such an analysis and uses it to develop the hypothesis that grounds the paper's call for reform: courts conducting harmless-error review must reverse judgments that infringe the appellant's or petitioner's life, liberty, or property interests through an ongoing unconstitutional application of positive law but are otherwise free-at least so far as the Constitution is concerned-to exercise guided discretion in deciding whether an error warrants a remedy.

\section{A. A Brief History}

1. Harmless Error on Direct Review. The harmless-error doctrine, like so many other American legal doctrines, finds its roots in the English common law. ${ }^{18}$ Historical accounts of the harmless-error doctrine's development frequently begin with Crease v. Barrett, ${ }^{19}$ an 1835 decision of the Court of the Exchequer that curtailed the then-prevalent practice in English appellate courts to affirm any judgment which, in the opinion of the reviewing court, had reached the correct result. ${ }^{20}$ The Crease decision became associated-incorrectly, in the view of Justice Traynor-with an emergent, mid-nineteenth century English practice of reversing nearly all criminal and civil judgments tied to proceedings in which some error had occurred. ${ }^{21}$

In 1873, Parliament responded to this perceived appellate hypertechnicality with a statute called the Judicature Act, whose purpose was to encourage reviewing courts to return to the practice of vacating or reversing civil judgments only if they thought that the wrong party had won. ${ }^{22}$ The Judicature Act was ineffective; appellate judges continued to order new trials in almost all cases in which they found error. ${ }^{23}$ In 1907, Parliament tried again with another new law called the Criminal Appeal Act, which directed appellate judges to dismiss criminal appeals, notwithstanding any meritorious assertion of error, if "no substantial miscarriage of justice has actually occurred." ${ }^{24}$ Once

\footnotetext{
18. See TRAYNOR, supra note 1 , at 4 .

19. (1835) 149 Eng. Rep. 1353, 1359.

20. See TRAYNOR, supra note 1, at 6-8.

21. See id. at 4-8 (disagreeing with the depiction of Crease as having adopted a rule of near automatic reversal and laying the blame for its mischaracterization on subsequent English decisions which did not accurately describe its holding, and on John Henry Wigmore, who accepted the accuracy of these mischaracterizations in his famous treatise on evidence) (citing 1 J. WIGMORE, EVIDENCE $§ 21$, at 368 (3d ed. 1940))

22. See TRAYNOR, supra note 1, at 8-9 (citing the Judicature Act of 1873, 36 \& 37 Vict., c. 66 ๑ 48)

23. See TRAYNOR, supra note 1 , at $9-10$.

24. See id. at 10-11 (citing the Criminal Appeal Act of 1907, 7 Edw. 7, c. 23, § 4(1)).
} 
again, however, English judges largely ignored the statute and continued to reverse with great frequency-a result Traynor found surprising in view of the fact that, in the English system, the double jeopardy doctrine precluded retrial upon reversal of a criminal judgment. ${ }^{25}$

In the late nineteenth and early twentieth centuries, American appellate courts behaved much like their English counterparts, applying a rule approximating automatic reversal. ${ }^{26}$ Retrials were common, and appellate courts were criticized for "tower[ing] above the trials of criminal cases as impregnable citadels of technicality." ${ }^{27}$ In 1946, in Kotteakos $v$. United States, the Supreme Court characterized the era as follows: "So great was the threat of reversal, in many jurisdictions, that criminal trial became a game for sowing reversible error in the record, only to have repeated the same matching of wits when a new trial had been thus obtained." 28

American appellate hypertechnicality spurred federal and state legislative reform efforts, which were led by prominent members of the bar and legal academy. ${ }^{29}$ In 1919, after considerable deliberation, Congress enacted a federal harmless-error statute, Judicial Code $\S 269,28$ U.S.C. $§ 391$, which provided:

On the hearing of any appeal, certiorari, writ of error, or motion for a new trial, in any case, civil or criminal, the court shall give judgment after an examination of the entire record before the court, without regard to technical errors, defects, or exceptions which do not affect the substantial rights of the parties. ${ }^{30}$

25. See TRAYNOR, supra note 1, at 11 .

26. See John M. M. Greabe, Spelling Guilt Out of a Record? Harmless-Error Review of Conclusive Mandatory Presumptions and Elemental Misdescriptions, 74 B.U. L. REV. 819, 823 (1994). I draw with liberality from my previous article in sketching the development of harmless-error review in the United States.

27. Marcus A. Kavanagh, Improvement of Administration of Criminal Justice by Exercise of Judicial Power, 11 A.B.A. J. 217, 222 (1925) (quoted in Kotteakos v. United States, 328 U.S. 750,759 (1946)).

28. 328 U.S. at 759.

29. See Fairfax, supra note 15, at 2033 (observing that one prominent reform committee included Felix Frankfurter, Roscoe Pound, and William H. Taft); see also Kotteakos, 328 U.S. at 758-60 \& nn.10-14 (providing examples of the extent of legislative reform efforts and the extensive commentary of prominent legal scholars).

30. Act of Feb. 26, 1919, ch. 48, 40 Stat. 1181, repealed by Act of June 25, 1948, ch. $646, \S 39,62$ Stat. 892, 998. 
By 1926, eighteen states also had enacted laws directing their appellate courts to ignore harmless errors, and ten more had established some sort of similar rule by judicial pronouncement. ${ }^{31}$

These reform efforts did not have the impact for which their proponents had hoped, as American appellate courts continued to vacate and reverse with great frequency over the next couple of decades. ${ }^{32}$ In the mid-1940s, however, Congress and the Supreme Court took additional steps towards implementing a more rigorous application of harmless-error review. Congress did so by acquiescing in the promulgation of the Federal Rules of Criminal Procedure, which contained a harmless-error provision that tracked the language of the 1919 federal harmless-error statute but omitted the descriptor "technical" before the word "errors." 33 The Supreme Court did so in its Kotteakos decision, which constituted the first serious elaboration of how courts should conduct harmless-error review under the 1919 statute.

In Kotteakos, a jury had convicted the petitioners of a single conspiracy to violate the National Housing Act even though, as the government admitted on appeal, the evidence had established eight or more different conspiracies of the same sort conducted through a common figure. ${ }^{34}$ The question presented was whether the variance between the single conspiracy charged in the indictment and the multiple conspiracies proved at trial constituted a technical error or defect that did not affect the substantial rights of the parties within the meaning of the federal harmless-error statute. ${ }^{35}$ Holding that the error did not fall within the reach of the statute and therefore required the

31. See Greabe, supra note 26, at 823 n.23 (citing 3 WAYNE R. LAFAVE \& JEROLD H. ISRAEL, CRIMINAL PROCEDURE § 26.6(a), at 258 n.5 (1984)) (internal citations omitted).

32. See Fairfax, supra note 15, at 2034.

33. Id. (quoting FED. R. CRIM. P. 52(a), which provided that "[a]ny error, defect, irregularity, or variance that does not affect substantial rights must be disregarded"). The then recently enacted Federal Rules of Civil Procedure also contained a harmless-error provision, FED. R. CIV. P. 61. In 1948, Congress repealed the 1919 federal harmless-error statute, see supra note 30, on the view that the Federal Rules of Criminal and Civil Procedure now contained the necessary directives. See Meltzer, supra note 8, at 21 \& n.86. In 1949, however, Congress enacted the current federal harmless-error statute, 28 U.S.C. $\S 2111$, out of an apparently misplaced concern that the Federal Rules applied only to federal district courts, and not to federal appeals courts or the U.S. Supreme Court. See id. (citing H.R. REP. NO. 81-352 (1949), as reprinted in 1949 U.S.C. CONG. SERV. 1248, 1272 ); see also Act of May 24, 1949, ch. $139 \S 110,63$ Stat. 105 (codified at 28 U.S.C. $\S 2111)$. The 1949 enactment also omits the adjective "technical," which had modified the phrase "errors, defects, or exceptions which do not affect the substantial rights of the parties" in the 1919 statute. See supra note 30 and accompanying text. It thus directs reviewing courts to disregard all errors that do not affect substantial rights. See supra note 9 for the full text of $\S 2111$.

34. 328 U.S. at 752 .

35. See id. at $757-58$. 
award of a new trial, ${ }^{36}$ the Supreme Court clarified that the question hinged on whether the error had "substantial and injurious effect or influence in determining the jury's verdict." 37

In a thoughtful passage elaborating what the analysis under this standard should entail, Justice Rutledge stated:

Some aids to right judgment may be stated more safely in the negative than in affirmative form. Thus, it is not the appellate court's function to determine guilt or innocence.... Nor is it to speculate upon probable reconviction and decide according to how the speculation comes out. Appellate judges cannot escape such impressions. But they may not make them sole criteria for reversal or affirmance. Those judgments are exclusively for the jury, given always the necessary minimum evidence legally sufficient to sustain the conviction unaffected by the error .... .

But this does not mean that the appellate court can escape altogether taking account of the outcome. To weigh the error's effect against the entire setting of the record without relation to the verdict or judgment would be almost to work in a vacuum .... In criminal causes that outcome is conviction. This is different, or may be, from guilt in fact. It is guilt in law, established by the judgment of laymen. And the question is, not were [the jurors] right in their judgment, regardless of the error or its effect upon the verdict. It is rather what effect the error had or reasonably may be taken to have had upon the jury's decision. The crucial thing is the impact of the thing done wrong on the minds of other men, not on one's own, in the total setting ....

This must take account of what the error meant to them, not singled out and standing alone, but in relation to all else that happened. And one must judge others' reactions not by his own, but with allowance for how others might react and not be regarded generally as acting without reason. This is the important difference, but one easy to ignore when the sense of guilt comes strongly from the record.

If, when all is said and done, the conviction is sure that the error did not influence the jury, or had but very slight effect, the verdict and judgment should stand, except perhaps where the departure is from a constitutional norm or a specific command of Congress.... But if one cannot say, with fair assurance, after pondering all that happened

\footnotetext{
36. See id. at 776.

37. Id. at 776 .
} 
without stripping the erroneous action from the whole, that the judgment was not substantially swayed by the error, it is impossible to conclude that substantial rights were not affected. The inquiry cannot be merely whether there was enough to support the result, apart from the phase affected by the error. It is rather, even so, whether the error itself had substantial influence. If so, or if one is left in grave doubt, the conviction cannot stand. ${ }^{38}$

The dictum "perhaps" exempting constitutional errors from operation of the statute reflected the practice of the time, which was to regard an appellate remedy as mandatory in the event of constitutional error. ${ }^{39}$

For the next twenty years or so, the Supreme Court treated 28 U.S.C. §2111-the new federal harmless-error statute that Congress enacted in 1949 to replace the 1919 harmless-error statute $^{40}$ - as always requiring a new trial if constitutional error had occurred during the initial trial. ${ }^{41}$ But in 1963, in Fahy $v$. Connecticut, ${ }^{42}$ the Court retreated from this approach and explicitly raised the question whether the erroneous admission of evidence obtained by means of a search and seizure that had violated the Fourth Amendment "can . . . be subject to the normal rules of 'harmless error' under the federal standard of what constitutes harmless error." 43 Yet the Court declined to decide the question it had raised because the admission of evidence at the petitioner's trial had been "prejudicial," a term that the Court defined by stating that "there is a reasonable possibility that the

38. Id. at 763-65 (citations and footnotes omitted).

39. Greabe, supra note 26, at 824 \& n.33 (citing 3 LAFAVE \& ISRAEL, supra note 31 , at 270). It is not clear why Kotteakos treated the error-the variance between the conspiracy charged and the conspiracies proved-as nonconstitutional. The Fifth Amendment provides a right of grand jury indictment for an "infamous crime" of the type for which the petitioners stood convicted, and the petitioners were not indicted for the crimes that the evidence tended to prove. See U.S. ConsT. amend. V. Moreover, the Sixth Amendment provides a right "to be informed of the nature and cause of the accusation." U.S. CONST. amend. VI. One court has suggested that the prohibition on variances between a single conspiracy charged in the indictment and multiple conspiracies being proved at trial should be understood as a "common law" rule or a rule derived from the rules prohibiting prejudicial joinder, and not a constitutional rule. See United States v. Baughm, 449 F.3d 167, 175-76 (D.C. Cir. 2006). But the court fails to provide a convincing explanation why the victim of such a variance has not suffered a violation of his or her Fifth and Sixth Amendment rights.

40. See supra note 33 (explaining the history behind Congress's 1948 repeal of the 1919 federal harmless-error statute and its 1949 enactment of 28 U.S.C. § 2111).

41. See Greabe, supra note 26, at 825 (citing Ogletree, supra note 15, at $157 \&$ n. 43 (collecting cases)).

42. 375 U.S. 85 (1963).

43. Id. at 86. 
evidence complained of might have contributed to the conviction." 44

During these same two decades, the Warren Court was famously expanding the reach of federal constitutional protections for criminal defendants. ${ }^{45}$ Thus, by the time Chapman v. California reached the Court in 1967, ${ }^{46}$ the field of constitutional criminal procedure was ripe for what Justice Benjamin Cardozo described as "taming," a process by which novel and potentially far-reaching legal principles are "reduc[ed]... to something that is both apparently more clear and more objective, and apparently less threatening to established institutions." 47 Chapman and its progeny have certainly served as taming influences in the criminal procedure field. ${ }^{48}$

Chapman, which reached the Supreme Court from the California state court system, involved a situation where a prosecutor had commented on the silence of the accused, ${ }^{49}$ a practice held unconstitutional in Griffin v. California in 1965. ${ }^{50}$ The California Supreme Court applied the state's harmless-error rule, which directed courts to ignore errors that had not caused a miscarriage of justice, ${ }^{51}$ and affirmed the

44. Id. at 86-87.

45. See, e.g., id.; Mapp v. Ohio, 367 U.S. 643, 655 (1961) (holding that state courts must exclude evidence obtained in violation of the Fourth Amendment); Gideon v. Wainwright, 372 U.S. 335, 342-45 (1963) (holding that indigent criminal defendants have a fundamental Sixth Amendment right to assistance of counsel); Miranda v. Arizona, 384 U.S. 436, 444 (1966) (holding that the Fifth Amendment privilege against self-incrimination requires law enforcement officials to apprise those in custody of certain rights).

46. 386 U.S. 18 (1967).

47. Greabe, supra note 26, at 825 n.37 (citing Benjamin N. CARdozo, The Nature OF THE Judicial PROCEss 51 (1921)); Craig Goldblatt, Comment, Disentangling Webb: Governmental Intimidation of Defense Witnesses and Harmless Error Analysis, 59 U. CHI. L. REV. 1239, 1243 n.25 (1992) (same).

48. See Greabe, supra note 26, at 825; Ogletree, supra note 15, at 158 (arguing that the harmless error rule of Chapman $v$. California has had the effect of practically diluting many of the constitutional procedural protections first recognized by the Warren Court).

49. Chapman, 386 U.S. at 19.

50. 380 U.S. 609, 613 (1965) (holding that prosecutorial comment about the accused's failure to testify infringes the accused's Fifth Amendment privilege against self-incrimination).

51. CAL. CONST. art. VI, § 13 provides:

No judgment shall be set aside, or new trial granted, in any cause, on the ground of misdirection of the jury, or of the improper admission or rejection of evidence, or for any error as to any matter of pleading, or for any error as to any matter of procedure, unless, after an examination of the entire cause, including the evidence, the court shall be of the opinion that the error complained of has resulted in a miscarriage of justice. 
underlying convictions. ${ }^{52}$ The U.S. Supreme Court reversed, finding that the error had not been harmless. ${ }^{53}$ But importantly, the Court for the first time explicitly acknowledged that "there may be some constitutional errors which in the setting of a particular case are so unimportant and insignificant that they may . . . be deemed harmless." ${ }^{54}$

Justice Black wrote the majority opinion for himself and six others. He started by observing that "[w] hether a conviction for a crime should stand when a State has failed to accord federal constitutionally guaranteed rights is every bit as much of a federal question as what particular federal constitutional provisions mean, what they guarantee, and whether they have been denied." 55 He then elaborated:

With faithfulness to the constitutional union of the States, we cannot leave to the States the formulation of the authoritative laws, rules, and remedies designed to protect people from actions by the States of federally guaranteed rights. We have no hesitation in saying that the right of these petitioners not to be punished for exercising their Fifth and Fourteenth Amendment right to be silentexpressly created by the Federal Constitution itself-is a federal right which, in the absence of appropriate congressional action, it is our responsibility to protect by fashioning the necessary rule. ${ }^{56}$

Justice Stewart would have avoided the harmless-error question and therefore concurred only in the judgment; he would have held that a state prosecutor's violation of the rule in Griffin $v$. California should trigger an automatic reversal. ${ }^{57}$ Justice Harlan dissented on the ground that "a state appellate court's reasonable application of a constitutionally appropriate state harmless-error rule to sustain a state conviction constitutes an independent and adequate state ground of judgment." 58

In proceeding to "fashion[]" a harmless-error rule applicable to federal constitutional error, Justice Black stated that he and others in the majority "prefer the [Fahy $v$. Connecticut] approach... in deciding what was harmless error"- "whether there is a reasonable possibility that the evidence complained of

\footnotetext{
52. Chapman, 386 U.S. at 19-20.

53. See id. at 24-26.

54. Id. at 22 .

55. Id. at 21 .

56. Id.

57. See id. at 45 (Stewart, J., concurring in the result).

58. Id. at 46 (Harlan, J., dissenting).
} 
might have contributed to the conviction" 59 - to the California Constitution's miscarriage-of-justice rule. ${ }^{60} \mathrm{He}$ then equated the Fahy statement with the harmless-error principle for which Chapman has become known, and stated the Court's holding: "We, therefore, do no more than adhere to the meaning of [Fahy] when we hold, as we now do, that before a federal constitutional error can be held harmless, the court must be able to declare a belief that it was harmless beyond a reasonable doubt." 61

In the course of fashioning a new standard of review for constitutional error, the Chapman majority did not mention 28 U.S.C. $\$ 2111$, the federal harmless-error statute, or allude to the harmless-error analysis conducted in Kotteakos (which was, as we have seen, an elaboration of $\S 2111$ 's statutory predecessor). Subsequently, however, the Supreme Court has made it clear that the Kotteakos inquiry into whether the error "had substantial and injurious effect or influence in determining the jury's verdict" 62 is to govern nonconstitutional error, whereas the Chapman analysis is to apply to constitutional error. ${ }^{63}$ The Court also has emphasized that it regards the Kotteakos analysis as significantly "more forgiving" than the analysis prescribed in Chapman. ${ }^{64}$

In the years since Chapman, the Supreme Court has flirted with three distinct techniques for determining whether an error is harmless beyond a reasonable doubt. ${ }^{65}$ The first, suggested by Chapman itself, ${ }^{66}$ examines only the extent to which the

59. Id. at 23 (quoting Fahy v. Connecticut, 375 U.S. 85, 86-87 (1963)) (internal quotation marks omitted). For a discussion of Fahy, see supra notes 42-44 and accompanying text.

60. Chapman, 386 U.S. at 22-23. For a statement of relevant California law, see supra note 51 and accompanying text.

61. Chapman, 386 U.S. at 24.

62. Kotteakos v. United States, 328 U.S. 750, 776 (1946).

63. See, e.g., United States v. Lane, 474 U.S. 438, 445-49 (1986).

64. See, e.g., Fry v. Pliler, 511 U.S. 112, 116 (2007); see also infra notes 96-97 and accompanying text (noting that, in Brecht v. Abrahamson, 507 U.S. 619, 621 (1993), the Court held that constitutional errors challenged on collateral review should be assessed for harmlessness under the Kotteakos/§ 2111 test, which it described as "less onerous" than the "stringent" Chapman test). One lower court has characterized the Kotteakos/§ 2111 analysis as requiring a reversal unless it is "more probable than not that the error did not materially affect the verdict." United States v. Laurienti, 611 F.3d 530, 547 (9th Cir. 2010). Compare id., with Stockman v. Oakcrest Dental Ctr., P.C., 480 F.3d 791, 799 (6th Cir. 2007) (stating that nonconstitutional error should be treated as harmless "unless it is more probable than not that the error materially affected the verdict" (internal quotation omitted)).

65. See Greabe, supra note 26 , at $828-29$

66. 386 U.S. at $23-24$ ("An error in admitting plainly relevant evidence which possibly influenced the jury adversely to a litigant cannot... be conceived of as harmless."). 
erroneously admitted material tends to be incriminating, without regard to the untainted evidence. ${ }^{67}$ The second looks to whether the error was "cumulative"-i.e., duplicative of untainted evidence tending to establish the same fact or facts supported by the erroneously admitted material. ${ }^{68}$ The third analyzes whether the jury likely gave the erroneously admitted material significant weight in light of the entire record. ${ }^{69}$ The Court appears to have settled on the third technique as the one reviewing courts should employ. ${ }^{70}$

In holding that constitutional errors should be disregarded if shown to have been harmless beyond a reasonable doubt, ${ }^{71}$ the Chapman majority acknowledged, and did not retreat from, prior decisions indicating "that there are some constitutional rights so basic to a fair trial that their infraction can never be treated as harmless error ...."72 The majority listed three such rights-the right not to have a coerced confession introduced into evidence, the right to counsel, and the right to an impartial judge-in terms suggesting that the list was not necessarily exhaustive. ${ }^{73}$

67. See Greabe, supra note 26, at 828 (citing 3 LAFAVE \& ISRAEL, supra note 31, at 279-81); Martha A. Field, Assessing the Harmlessness of Federal Constitutional Error-A Process in Need of a Rationale, 125 U. PA. L. REV. 15, 16 (1977)).

68. See Greabe, supra note 26, at 828 (citing Harrington v. California, 395 U.S. 250, 254 (1969)); Field, supra note 67, at 37).

69. Greabe, supra note 26, at 822-23; see Field, supra note 67, at 21-22; see Greabe, supra note 26, at 828-29 (citing Yates v. United States, 500 U.S. 391, 403-04 (1991)).

70. Greabe, supra note 26 at 829 (citing Yates, 500 U.S. at 403-04 (clarifying that Chapman requires reviewing courts to weigh the probative force of the untainted evidence against the probative force of the erroneously admitted material standing alone and to determine the likely significance of the error upon reasonable jurors); 3 LAFAVE \& ISRAEL, supra note 31, at 281 n.5); see also Sullivan v. Louisiana, 508 U.S. 275, 279-80 (1993) (endorsing and applying the Yates analysis). The Court has at other times and in other contexts suggested that the presence of overwhelming evidence of guilt alone renders an error harmless. See Greabe, supra note 26, at 829 n.67 (citing, e.g., United States v. Hasting, 461 U.S. 499, 510-11 (1983)) ("The question a reviewing court must ask is this: absent [the improperly admitted material], is it clear beyond a reasonable doubt that the jury would have returned a verdict of guilty?"); Milton v. Wainright, 407 U.S. 371, 372-73 (1972) (similar); Schneble v. Florida, 405 U.S. 427, 431-32 (1972) (similar)). But these statements-which are akin to a "correct result" test of the sort rejected in Chapman, see 386 U.S. at 23-24-are contradicted by the Court's more carefully reasoned cases, and should not be taken to express the proper formulation. See Greabe, supra note 26, at 829 n.67 (citing 3 LAFAVE \& ISRAEL, supra note 31 , at 279, 281). But see United States v. Vazquez, 132 S. Ct. 1532, 1532 (2012) (dismissing writ of certiorari as improvidently granted with respect to a Seventh Circuit decision in which a split panel arguably used different harmless-error approaches and the majority arguably used the "correct result" approach); Anne Bowen Poulin, Tests for Harm in Criminal Cases: A Fix for Blurred Lines, 17 U. PA. J. CONST. L. 991, 992-93 (2015) (discussing Vazquez and opining that "[e]xisting Supreme Court precedent does not clearly endorse" any one approach to harmless-error review).

71. Chapman, 386 U.S. at 24 .

72. Id. at 23 .

73. Id. at 23 n. 8 (citations omitted). 
In the following quarter century or so, the Court placed additional rights within this category on an ad hoc basis. ${ }^{74}$ But it failed to explain how courts should determine whether a given constitutional error is amenable to harmless-error review until 1991, when it decided Arizona v. Fulminante. ${ }^{75}$

In Fulminante, a highly fractured Court returned to the question whether the erroneous admission into evidence of a coerced confession should be subject to harmless-error review under the Chapman principle. ${ }^{76}$ In answering that it should, ${ }^{77}$ the Court provided a framework for determining whether other constitutional errors should be subjected to analysis under Chapman. The Court bifurcated the universe of constitutional error and suggested that most errors fall into a default category of "trial" errors- "error[s] which occur[ during the presentation of the case to the jury, and which may therefore be quantitatively assessed in the context of other evidence presented in order to determine whether [their] admission was harmless." "78 But the Court also acknowledged a second category of "structural defects"- "defects in the constitution of the trial mechanism, which defy analysis by harmless-error standards."79 More recently, in United States v. Gonzalez-Lopez, the Court explained that structural defects "bear[] directly on the framework within which the trial proceeds." 80 It then provided a list of errors that cause such structural defects: errors having the effect of denying the right to counsel, ${ }^{81}$ self-representation, ${ }^{82}$ a public trial, ${ }^{83}$ and an appropriate reasonable-doubt instruction. ${ }^{84}$ The Court went

74. See, e.g., Waller v. Georgia, 467 U.S. 39, 49 n.9 (1984) (right to a public trial); McKaskle v. Wiggins, 465 U.S. 168, 177 n.8 (1984) (right to self-representation).

75. 499 U.S. 279 (1991). JJ.).

76. Id. at 306-12 (Rehnquist, C.J., joined by O'Connor, Scalia, Kennedy, and Souter,

77. See id. at 288, 308-09 (rejecting suggestions to the contrary in Chapman, 386 U.S. at 23 \& n.8, Jackson v. Denno, 378 U.S. 368, 376 (1964), and Payne v. Arkansas, 356 U.S. 560, 567-68 (1958)). The Fulminante decision contained three different 5-4 majorities. As just stated, five members of the Court concluded that the admission of a coerced confession could in some circumstances be harmless. Id. at 302-03. A second five justice majority determined that the confession at issue had indeed been coerced. See id. at 282, 285-88 (White, J., joined by Marshall, Blackmun, Stevens, and Scalia, JJ.). Finally, a third five justice majority decided that the State had not demonstrated the error to be harmless. See id. at 295-302 (White, J., joined by Marshall, Blackmun, Stevens, and Kennedy, JJ.).

78. Id. at $307-08$

79. Id. at 309 (internal quotation marks omitted).

80. 548 U.S. $140,148,150$ (2006).

81. See id. at 149-50 (citing Gideon v. Wainwright, 372 U.S. 335, 344-45 (1963)).

82. See id. at 149 (citing McKaskle v. Wiggins, 465 U.S. 168, 177-78 \& n.8 (1984)).

83. See id. (citing Waller v. Georgia, 467 U.S. 39, 49 n.9 (1984)).

84. See id. (citing Sullivan v. Louisiana, 508 U.S. 275 (1993)). 
on to add to the list errors that have the effect of denying the right to counsel of one's choice. ${ }^{85}$

2. Harmless Error on Collateral Review. From 1967 to 1993, the Supreme Court applied the Chapman principle to all constitutional errors amenable to harmless-error review, regardless of whether it was conducting direct review of a state court judgment, ${ }^{86}$ direct review of a federal court judgment, ${ }^{87}$ or review of a federal judgment resolving a collateral attack on a state court judgment. ${ }^{88}$ But in 1993, in Brecht $v$. Abrahamson, ${ }^{89}$ the Court held that federal courts conducting collateral review of state convictions marred by constitutional error should apply the harmless-error standard from Kotteakos v. United States, ${ }^{90}$ which until then had been applied only to nonconstitutional errors in federal criminal cases. ${ }^{91}$ Thus, a federal court conducting habeas corpus review of a state court criminal judgment infected by federal constitutional error should leave the judgment undisturbed unless the error was shown to have had a "substantial and injurious effect or influence in determining the jury's verdict"-a showing that was further described as requiring habeas petitioners to establish more than just a "reasonable possibility" that the error contributed to the verdict, and that the error had resulted in "actual prejudice." 92

Brecht involved a situation where a state prosecutor had used a state criminal defendant's silence after receiving the warnings prescribed by Miranda $v$. Arizona ${ }^{93}$ to impeach the defendant at trial. ${ }^{94}$ After stating that the error fell within Fulminante's "trial error" category, ${ }^{95}$ the Court considered whether it should conduct harmless-error review under what it

\footnotetext{
85. See id. at 150. This past Term, the Court also held that the unconstitutional participation in appellate proceedings by a presumptively biased judge constitutes structural error. Williams v. Pennsylvania, 136 S. Ct. 1899, 1909 (2016).

86. See, e.g., Chapman v. California, 386 U.S. 18, 24-26 (1967).

87. See, e.g., United States v. Hasting, 461 U.S. 499, 510-11 (1983).

88. See, e.g., Yates v. Evatt, 500 U.S. 391, 402 (1991); Rose v. Clark, 478 U.S. 570, 579-80 (1986); Milton v. Wainwright, 407 U.S. 371, 372-73 (1972); Anderson v. Nelson, 390 U.S. 523, 523-24 (1968) (per curiam).

89. 507 U.S. $619,631-33$ (1993).

90. 328 U.S. 750, 764-65 (1946). For a discussion of Kotteakos, see supra notes 34-39 and accompanying text.

91. See Brecht, 507 U.S. at 631-32.

92. Id. at 637 (citations and internal quotation marks omitted).

93. 384 U.S. 436, 444 (1966).

94. See Brecht, 507 U.S. at 622-23. Such commentary violates a criminal defendant's due process rights. See Doyle v. Ohio, 426 U.S. 610, 618 (1976).

95. See supra note 78 and accompanying text.
} 
called the "stringent" Chapman principle" 96 or the "less onerous" Kotteakos standard. ${ }^{97}$ The Court opted for the latter, emphasizing the state's interest in the finality of convictions that have survived direct review, comity, federalism, the interest of maintaining the prominence of the trial itself (which often had occurred years earlier), the difficulty of retrials years after the original trial, and a perceived imbalance of other costs and benefits of applying Chapman on collateral review. ${ }^{98}$ Assessing the error under the Kotteakos standard, the Court concluded that it had not had a substantial and injurious effect or influence in determining the jury's verdict because the State's references to petitioner's post-Miranda silence were infrequent and because the evidence of petitioner's guilt was, "if not overwhelming, then certainly weighty." 99

Three years after Brecht, Congress enacted the Antiterrorism and Effective Death Penalty Act of 1996, widely known as the "AEDPA."100 The AEDPA contains a provision, 28 U.S.C. $\S 2254(\mathrm{~d})(1)$, that prohibits the granting of a federal habeas petition on the ground that a state court has improperly adjudicated a federal constitutional claim on the merits unless the state's decision "was contrary to, or involved an unreasonable application of, clearly established Federal law, as determined by the Supreme Court of the United States...."101 In 2003, in Mitchell v. Esparza, the Court held that $\S 2254(\mathrm{~d})(1)$ applies to state appellate court determinations that a constitutional violation is harmless under Chapman and precludes an award of relief unless the state court's application of Chapman was itself unreasonable. ${ }^{102}$

In 2007, in Fry $v$. Pliler, the Court affirmed Brecht's continuing relevance post-AEDPA by rejecting the argument that $\S 2254(\mathrm{~d})(1)$, as interpreted in Esparza, eliminates the requirement that a habeas petitioner satisfy the Brecht/Kotteakos harmless-error standard in order to obtain a remedy on habeas corpus review. ${ }^{103}$ Rather, Fry held, courts should continue to treat satisfaction of the Brecht/Kotteakos test as a precondition of collateral relief. ${ }^{104}$ In reaching this

\footnotetext{
96. Brecht, 507 U.S. at 632.

97. Id. at 637 .

98. See id. at $635-37$.

99. See id. at 638-39.

100. See supra note 17 and accompanying text.

101. See id. for the entire text of 28 U.S.C. $§ 2254$ (d).

102. 540 U.S. $12,17-18$ (2003) (per curiam).

103. 551 U.S. 112, 119-20 (2007).

104. See id. at 119.
} 
conclusion, the Court stated that it was "implausible" that the AEDPA-which sought to limit rather than expand the availability of habeas relief-would replace "the Brecht standard of 'actual prejudice' with the more liberal AEDPA/Chapman standard which requires only that the state court's harmless -beyond-a-reasonable-doubt determination be unreasonable." 105 The Court continued: "That said, it certainly makes no sense to require formal application of both tests (AEDPA/Chapman and Brecht) when the latter obviously subsumes the former." 106

Confusingly, however, in its 2015 decision in Davis v. Ayala, the Court criticized the Ninth Circuit for reading Fry as authorizing courts entertaining habeas petitions to skip to the end and only apply the less forgiving Brecht/Kotteakos harmless-error standard in cases where they conclude that a petitioner has satisfied the standard. ${ }^{107}$ The Court stated that, while (per Fry) a federal habeas court need not formally apply both the Brecht/Kotteakos and AEDPA/Chapman tests, "that does not mean, as the Ninth Circuit thought, that a state court's harmlessness determination has no significance under Brecht." 108 Thus, although the Brecht/Kotteakos test "obviously subsumes" the AEDPA/Chapman test, ${ }^{109}$ reviewing courts convinced that an award of relief is appropriate should not simply apply the Brecht/Kotteakos test without also taking stock of whether a state appellate court's Chapman analysis was unreasonable within the meaning of $\S 2254(\mathrm{~d}) .{ }^{110}$ The Court also emphasized that, in order to conclude that a state appellate court's finding of harmlessness under Chapman was unreasonable, a habeas court must find that "fair-minded jurists could [not] disagree on its correctness"-i.e., that the state appellate court's decision "was so lacking in justification that there was an error well understood and comprehended in existing law beyond any possibility for fairminded disagreement." 111

3. Summary. We have seen that federal harmless-error doctrine has evolved in such a way that it now encompasses a multi-tiered system that distinguishes among four different

\footnotetext{
105. Id. at 119-20 (citations omitted)

106. Id. at 120 .

107. See 135 S. Ct. 2187, 2198 (2015).

108. Id. ("The Fry Court did not hold-and would have had no possible basis for holding - that Brecht somehow abrogates the limitation on federal habeas relief that $\S 2254$ (d) plainly sets out.”).

109. See supra note 106 and accompanying text.

110. See Davis, 135 S. Ct. at 2198.

111. Id. at 2199 (citations and internal quotation marks omitted).
} 
categories of error: (1) constitutional "structural" errors, which defy analysis by harmless-error review;112 (2) constitutional "trial" errors challenged on direct review, which are reviewed for harmlessness under the Chapman principle; ${ }^{113}$ (3) nonconstitutional trial errors challenged on direct review, which are reviewed for harmlessness under the Kotteakos test; ${ }^{114}$ and (4) constitutional trial errors challenged on collateral review, which also are reviewed for harmlessness under the Brecht/Kotteakos test. ${ }^{115}$ Beyond this, federal law also supplies a different, "plain-error" framework for evaluating errors as to which appellate rights have not been preserved. ${ }^{116}$ Under plain-error review, errors (even constitutional structural errors $)^{117}$ warrant vacatur or reversal only if they were obvious at the time they were committed, affected the substantial rights of the claiming party, and seriously affected the fairness, integrity, or public reputation of the judicial proceedings in which they occurred. ${ }^{118}$ And as set forth above, additional complications come into play when federal courts conduct collateral review of errors of federal constitutional law that have been found harmless by the state's appellate courts. ${ }^{119}$ Thus, the framework under which error is to be evaluated in the federal system is exceptionally complicated. ${ }^{120}$

\section{B. The Ontology of Chapman \& Its Progeny}

Because the Chapman majority said only that the case's holding was responsive to a "federal question," 121 the holding's

\footnotetext{
112. See supra note 79 and accompanying text.

113. See supra note 78 and accompanying text.

114. See supra notes $62-63$ and accompanying text. The Court has never suggested that a nonconstitutional trial error might be "structural"; indeed, it has implied the opposite. See Coenen, supra note 11, at 695 n.33.

115. See supra notes 89-91 and accompanying text.

116. See United States v. Olano, 507 U.S. 725, 732 (1993) (detailing how claims of error that have been forfeited should be reviewed for plain error under FED. R. CRIM. P. $52(b))$.

117. See Johnson v. United States, 520 U.S. 461, 466 (1997) (stating that structural errors are not subject to automatic reversal but, like other errors, are to be evaluated under the method prescribed in Rule 52(b) and Olano).

118. See Olano, 507 U.S. at 731-37.

119. See supra notes $102-111$ and accompanying text.

120. In an excellent recent article, Professor Anne Bowen Poulin canvasses the various tests (which include but are not limited to the harmless-error tests applied by reviewing courts and described above) under which courts evaluate the concept of "harm" in criminal cases. See Poulin, supra note 70, at 1007-13. As Professor Poulin demonstrates, the complexity of these various tests is truly mind-boggling.

121. See supra note 55 and accompanying text.
} 
essential nature (and, by extension, that of Fulminante ${ }^{122}$ and Brecht $\left.{ }^{123}\right)$ has perplexed commentators. In The Riddle of Harmless Error, published three years after Chapman, ${ }^{124}$ Justice Traynor defended the Chapman majority's "federal question" holding over Justice Harlan's dissenting objection ${ }^{125}$ that a state court's reasonable application of a state harmless-error rule should constitute an independent and adequate state ground of judgment not subject to federal review. ${ }^{126}$ But Traynor expressed puzzlement over why the Chapman majority had failed to recognize that the federal harmless-error statute, 28 U.S.C. $\S 2111$, and Federal Rule of Criminal Procedure 52(a) already occupied the terrain that Chapman purported to cover. ${ }^{127}$ Traynor thought that, going forward, the Court ought to rectify its oversight and rerationalize harmless-error doctrine as an interpretation of $\S 2111 .{ }^{128}$ Other analysts, in contrast, have suggested that the Chapman principle should be seen as constitutional in nature. ${ }^{129}$

Professor Daniel J. Meltzer refutes both positions in the most thorough analysis of Chapman's ontology that has been published to date. ${ }^{130}$ In disagreeing with Traynor that Chapman and its progeny are rooted (or at least ought to be seen as rooted) in $\S 2111$ and Rule 52(a), Meltzer first observes, correctly, that Rule 52(a) has no bearing on cases such as Chapman that originate in state courts. ${ }^{131}$ With respect to $\S 2111$, Meltzer notes that the statute enjoins courts to ignore errors that do not affect

\footnotetext{
122. See supra notes $75-79$ and accompanying text.

123. See supra notes 89-99 and accompanying text.

124. See supra notes 1-2.

125. See supra note 58 and accompanying text.

126. See TRAYNOR, supra note 1 , at 37-41. Traynor thought that a state harmless-error rule could apply only if it were procedural, and not substantive. See id. at 38-39. But in Traynor's view, state harmless-error rules are clearly substantive. See id. at 39-40 (stating that such a rule "has nothing to do with regulating the methods by which the facts are made known to the court" but rather is "of a piece with substantive rules, for it too is a mandate to the judge, at this stage the appellate judge, calling for the last word on the legal effect of the findings").

127. See id. at 42 .

128. See id. ("Once the Chapman case is viewed anew, the crucial question is one of statutory interpretation, the meaning of the words in Section 2111, 'errors or defects which do not affect substantial rights."). As we shall see, Justice Traynor then argued for abandonment of Chapman's beyond-a-reasonable-doubt standard in favor of an analysis, rooted in $\S 2111$, that would focus on whether it was "highly probable" that the error had not affected the jury. See id. at 43-51.

129. See supra note 6 and accompanying text.

130. See Meltzer, supra note 8, at 19-21, 26.

131. See id. at 19-20 (observing that the Federal Rules of Criminal Procedure regulate neither state court cases nor Supreme Court review of such cases but govern only federal court procedure in criminal cases).
} 
substantial rights; it does not direct them to vacate or reverse judgments where substantial rights are affected. ${ }^{132}$ Moreover, unlike Chapman, the statute neither explicitly regulates state courts engaged in harmless-error review nor differentiates between constitutional and nonconstitutional error. ${ }^{133}$ Thus, it is not plausible to view the Chapman principle as a product of statutory interpretation.

If the Chapman principle is not rooted in a federal statute, does it derive from the Constitution itself? In other words, is its implicit promise of a remedy unless the government establishes the harmlessness of a constitutional error beyond a reasonable doubt constitutionally compelled? Meltzer devotes much of his paper to consideration of this question, doing far more to develop an argument in favor of a constitutional basis for the Chapman principle than any writer who has so characterized the ruling. ${ }^{134}$ But Meltzer ultimately concludes that the Chapman principle is not derived from the Constitution, and, having thus eliminated both federal statutory law and the Constitution itself as potential sources of the rule, argues that it is an example of constitutional common law. ${ }^{135}$

As the next subsection explains, I agree with Meltzer that the remedy Chapman implicitly promises is not constitutionally compelled, with the qualification that the Constitution does require reviewing courts possessed of jurisdiction over a case to reverse when they find that an applicant for relief has been convicted under a statute that is unconstitutional, either facially

132. See id. at 20. Section 2111's preoccupation with authorizing reviewing courts to affirm some judgments notwithstanding the presence of error-rather than specifying when they should provide remedies-is understandable, Meltzer noted, when one appreciates that it was enacted to curb hypertechnical vacaturs and reversals. See id.; see also supra notes 26-39 and accompanying text (providing an overview of the historical period in question). The full text of $\S 2111$ is set forth in note 9, supra.

133. See Meltzer, supra note 8, at 21. Meltzer also briefly considered and rejected a second potential statutory argument-viz., that Chapman could be seen as necessary to preserve the Supreme Court's appellate jurisdiction to review federal constitutional rulings arising from the state courts. See id. at 21-23. The argument here would be that, if states were permitted to adopt harmless-error statutes that too readily withhold remedies for violations of federal constitutional rights, they effectively could insulate the underlying constitutional rulings from Supreme Court review under the independent-and-adequate state ground doctrine. See id. at 22. But as Meltzer observed, the Court could stymie such a possibility simply by holding the state ground for denying relief-i.e., harmlessness under a permissive state harmless-error statute-either "inadequate" to foreclose Supreme Court review, see id. at 22, or tantamount to a denial of state appellate review altogether, see id. at n.93. Either way, the Supreme Court then would be free to review the merits of the state court's federal constitutional ruling.

134. See id. at 1-26.

135. See id. at 26 . 
or as applied. 136 But I arrive at that conclusion through an examination of how vacating or reversing a criminal judgment functions as a remedy for a constitutional violation, and not through an ontological analysis of the sort Meltzer conducted. ${ }^{137}$ Still, because Meltzer's analysis is persuasive and corroborative, I precede my argument about what the Constitution requires with a summary of his, deferring to the next subsection consideration of Professor Richard M. Re's recent argument that the Chapman principle should be seen to originate in the due-process guarantee. ${ }^{138}$

The principal difficulty with any argument that the Constitution requires reviewing courts to provide remedies for constitutional errors not shown to have been harmless beyond a reasonable doubt is that the Supreme Court repeatedly has stated (albeit in dicta) that criminal defendants have no constitutional right to an appeal. ${ }^{139}$ For how can a remedy be constitutionally obligatory if its means of delivery is a matter of legislative grace? Meltzer first addresses whether these dicta are correct through consideration of a range of arguments that have been or could be made in favor of a constitutional right to an appeal.

The conventional view that there is no constitutional right to appeal a criminal judgment is grounded in the Constitution's text and history. The Constitution does not explicitly confer or implicitly assume such a right, no such right existed in English or colonial practice, and no such right was recognized in the States at the time of the Founding. ${ }^{140}$ Moreover, Congress provided no right to appeal criminal judgments in the federal courts when it enacted the Judiciary Act of $1789 .{ }^{141}$ Indeed, it was not until 1891 that Congress extended the right of appeal to all federal criminal defendants. ${ }^{142}$

\footnotetext{
136. See infra Part II.C. I also agree with Meltzer that the Chapman principle is best viewed as constitutional common law. See supra note 8 and accompanying text.

137. See infra Part II.C.

138. See Re, supra note 6, at 1914-16.

139. See Meltzer, supra note 8, at $2 \&$ nn.9-10 (collecting cases). Since Meltzer published his article, the Supreme Court has continued to state that the federal Constitution provides no right of appeal. See Martinez v. Court of Appeal, 528 U.S. 152, 160 (2000); M.L.B. v. S.L.J., 519 U.S. 102, 110 (1996); Goeke v. Branch, 514 U.S. 115, 119 (1995) (per curiam).

140. See Meltzer, supra note 8, at 6 \& nn.25-27 (collecting authority).

141. See id. at 6 \& n.28 (citing David Rossman, "Were There No Appeal": The History of Review in American Criminal Courts, 81 J. CRIM. L. \& CRIMINOLOGY 518, 522, 556-59 (1990)).

142. See id. at $6 \&$ n.29 (citing, inter alia, Act of Mar. 3, 1891, ch. 517 §, 26 Stat. 827).
} 
Nevertheless, several writers have argued that a more nuanced view of the history complicates any assertion that there was no right to appeal a criminal judgment at common law. ${ }^{143}$ In the eighteenth and nineteenth centuries, these writers point out, many jurisdictions employed procedures that served some of the functions of the modern appeal, including circuit riding, post-conviction motions, trials before multi-judge panels, executive and legislative review of criminal convictions, trial de novo in a higher court, and (sometimes) review by means of a writ of error. ${ }^{144}$ But, as Meltzer notes, the most that can be said of this history is that its existence complicates rejection of an argument for a constitutional right to appeal a conviction purely on the basis of history. The relevant history certainly does not provide fertile soil for the advancement of such an argument. ${ }^{145}$

Meltzer next addresses closely related arguments that appeals have assumed such importance in American state and federal criminal practice as to reflect a consensus that appellate review of convictions is now constitutionally necessary, ${ }^{146}$ and that proper application of the Mathews $v$. Eldridge balancing calculus ${ }^{147}$ reveals that a right to appeal a criminal conviction is now an aspect of American procedural due process. ${ }^{148}$ Meltzer finds more force in these arguments than in any argument from history. ${ }^{149}$ Still, Meltzer observes, there are important countervailing concerns ${ }^{150}$ and very strong reasons to doubt that today's Supreme Court would find these arguments persuasive. ${ }^{151}$

At this point, Meltzer switches gears and assumes arguendo that, notwithstanding what has just been said, there is a constitutional right to appeal criminal judgments. He then further assumes that this hypothetical right to appeal would require the provision of a remedy in at least some class of cases

\footnotetext{
143. See id. at 7 .

144. See id. at $7 \&$ nn.31-36 (collecting authority).

145. Id. at 8 .

146. See id.

147. See 424 U.S. 319, 334-35 (1976).

148. See Meltzer, supra note 8, at 8-9.

149. See id. at 9 .

150. See id. at 9 n.45 ("The massive increase in appellate dockets in recent years suggests that the institutional burden imposed by a constitutional right to appeal would be ... considerable" and that, therefore, "constitutionalizing a right to appeal might be thought to give insufficient weight to the third Mathews factor, the burden imposed on the government.").

151. See id. at 9 n.46, (explaining why, based on his or her voting history, each member of the 1994 Court would likely reject any argument that the Constitution confers on criminal defendants a right to appeal).
} 
involving judgments marred by error. ${ }^{152}$ Building from these assumptions, Meltzer considers whether the Chapman principle might be seen to operationalize such a right. He concludes, again convincingly, that the Chapman principle cannot plausibly be so characterized. For one thing, a right to reversal in certain circumstances derived from a constitutional right to appeal a criminal conviction seemingly would encompass any error that might have led (or probably led, or almost certainly led, etc.) to an erroneous conviction. But Chapman's implicit promise of a remedy for any error not shown to be harmless beyond a reasonable doubt extends only to federal constitutional error, and not to other outcome-affecting errors. ${ }^{153}$

Moreover, acceptance of a constitutional right to appeal in criminal cases cannot explain Chapman's requirement that state courts apply a federal harmless-error rule in deciding whether to provide a remedy for a federal constitutional error at trial. At most, such a right would promise an opportunity to challenge a state criminal conviction in a state intermediate appellate court. Assume that such a court, finding that federal constitutional error had occurred at trial, ignores Chapman and applies a more forgiving state harmless-error rule to affirm the conviction. The federal right to appeal a conviction would have been observed in such a situation, but not Chapman's additional mandate that a federal standard of review be applied to determine the availability of a remedy. Thus, Chapman requires more of state courts than vindication of any hypothetical federal constitutional right to an appeal in criminal cases. ${ }^{154}$

Having refuted the argument that the Chapman principle derives from a hypothetical (although doubtful) federal constitutional right to appeal a criminal conviction, Meltzer next considers whether it can be explained by other constitutional doctrines. Meltzer frames these arguments in terms of potential constitutional limits on "state power" to adopt a harmless-error principle other than Chapman, ${ }^{155}$ but his responses to these arguments also establish that there would be no constitutional barrier to the adoption of a rule other than Chapman to govern review of constitutional error at federal trials.

152. As Meltzer puts it, "Presumably, chief among the purposes of recognizing such a right would be to reduce the likelihood that a defendant has been convicted at a trial that violated his rights, constitutional or otherwise. To promote that purpose, an appeal must promise reversal of the conviction in appropriate cases." Id. at 10.

153. See id. at 10-11.

154. See id. at 11-12.

155. See id. at 12. Meltzer titles Part II of his article "Other Possible Constitutional Limits on State Power to Treat Errors as Harmless." Id. 
The first principle Meltzer evaluates is the Constitution's promise of equal protection in the provision of benefits that are not themselves constitutionally required-viz., the principle that, although the government need not provide criminal appeals, it cannot, for example, restrict the right to appeal "to persons who are white or Protestant or whose last names begin with $Q$." ${ }^{156}$ As Meltzer demonstrates, the Chapman principle does not derive from this equal protection principle. The adoption of a harmless-error rule materially different and more permissive than the one that Chapman prescribes-say, a rule that treats constitutional and nonconstitutional errors (whether state or federal) alike but permits courts to withhold remedies if they conclude that that the error probably did not affect the judgment-would not discriminate against either federal rights in general or particular federal rights. Nor would such a rule otherwise work a suspect classification. It therefore would not conflict with equal protection principles, for it could hardly be said to lack a rational basis. ${ }^{157}$

Next, Meltzer considers whether the Chapman principle is needed to avoid violating the unconstitutional conditions doctrine-viz., the principle that makes it unconstitutional, for example, for a state "to set up libraries restricted to Democratic users" even though "a state need not establish public libraries at all." 158 The unconstitutional conditions doctrine does not require the application of Chapman to constitutional trial errors. As Meltzer puts it:

$[\mathrm{T}] \mathrm{o}$ object that a state cannot condition its appeals on enforcement of a harmless-error standard less favorable to defendants than Chapman requires some independent explanation of why the Constitution requires the Chapman standard-an analogue to the First Amendment right of library patrons not to belong to the Democratic party [in the example recited above]. ${ }^{159}$

Thus, any argument based on the unconstitutional conditions doctrine brings us back to the problem of independently establishing a criminal defendant's constitutional right to

\footnotetext{
156. Id. (observing that this principle explains the Supreme Court's holdings that states may not constitutionally deny indigent appellants free transcripts, see Griffin v. Illinois, 351 U.S. 12, 18-19 (1956), or appointed counsel, see Douglas v. California, 372 U.S. 353, 356-58 (1963), or the effective assistance of counsel on appeal, see Evitts v. Lucey, 469 U.S. 387, 396 (1985)).

157. See id. at 14.

158. Id. (citing Kathleen M. Sullivan, Unconstitutional Conditions, 102 HARV. L. REV. 1413, 1421-28 (1989)).

159. Id. at $14-15$.
} 
application of the Chapman principle on review of a constitutional error committed at the defendant's trial. 160

Finally, Meltzer considers whether the Chapman principle might be tied to the rule of judicial integrity sometimes described in terms of a court's obligation to apply "all the relevant law," including the Constitution-an obligation that animated the analysis in Marbury $v$. Madison. ${ }^{161}$ Such an argument would begin with the premise that appellate courts, like other courts with jurisdiction over a case, are obliged to apply the Constitution to the cases they adjudicate. It might then conclude that application of the Constitution on appeal demands a remedy for criminal convictions tainted by constitutional error unless the requirements of the Chapman principle are satisfied. ${ }^{162}$ Yet any such argument runs up against (1) our history of regarding as valid recognized limitations on the power of appellate courts to consider only some of the issues presented in a given case, and (2) our more general practice of permitting courts to withhold remedies for past violations of constitutional rights. ${ }^{163}$ So long as we continue to accept the legitimacy of this firmly entrenched history and these remedial customs, the Chapman principle cannot be seen as a constitutional imperative that binds reviewing courts to provide remedies for constitutional trial errors unless the government has shown those errors to be harmless beyond a reasonable doubt. ${ }^{164}$

\section{Constitutional Obligation: A Working Hypothesis \& Response to Professor Re}

As noted in the previous subsection, Professor Meltzer's ontological analysis is convincing. Any claim that the Chapman principle finds its roots in the Constitution is undercut by the fact that there is no constitutional right to appeal a criminal judgment-a point that the Supreme Court has continued to

160. Id. at 15. Any argument that Chapman is constitutionally compelled based on the unconstitutional conditions doctrine also fails for a second reason: "Not all constitutional rights are implicated in unconstitutional conditions cases. By its very nature, the doctrine serves to protect only those rights that depend on some sort of exercise of autonomous choice by the rightholder, such as individual rights to speech, exercise of religion[,] or privacy ...." Id. at 15 (quoting Sullivan, supra note 158, at 1426) (internal quotation marks omitted). A more permissive harmless-error rule than Chapman would not put pressure on a criminal defendant to forego the exercise of his or her other constitutional rights. See id.

161. See id. at 15 (citing, inter alia, Marbury v. Madison, 5 U.S. (1 Cranch) 137, $177-78$ (1803)).

162. See id.

163. See id. at $16-17$.

164. See id. 
emphasize since Meltzer published his article ${ }^{165}$-and the additional fact that the Chapman principle cannot plausibly be traced to any doctrine that constrains government in the provision of constitutionally gratuitous benefits. Moreover, even if there were a constitutional right to appeal a criminal judgment, Chapman imposes obligations that make it impossible to characterize the Chapman principle as a logical extension of any such right.

But there is another path that leads to the conclusion that the remedy implicitly promised by the Chapman principle-i.e., vacatur or reversal unless the harmless-beyond-a-reasonable -doubt condition is satisfied-is not constitutionally compelled. The alternative path looks to how that remedy typically functions-viz., as a substitutionary remedy for the constitutional deprivation worked during the judicial proceedings that led to the claimant's conviction. For substitutionary constitutional remedies designed to ameliorate wholly concluded constitutional wrongs, although critical tools for incentivizing compliance with constitutional norms, are not themselves constitutionally necessary.

In recent work, I have developed and defended this argument, along with a corresponding claim that the Constitution does require remedies for ongoing constitutional injuries when relief is sought through justiciable and properly preserved claims brought in proper forums. ${ }^{166}$ This argument is descriptive in its origins; it is rooted in the extant doctrines and practices that combine to comprise the law of constitutional remedies. ${ }^{167}$ Yet the described reality-one that the Supreme

\footnotetext{
165. See supra note 139 and accompanying text.

166. See Greabe, supra note 8, at 919-23; see also John M. Greabe, Constitutional Remedies and Public Interest Balancing, 21 WM. \& MARY BILL RTS. J. 857, 892-96 (2013).
}

167. See Greabe, supra note 8, at 907-19; see also Greabe, supra note 166, at 863-92. My descriptive approach to the problem of constitutionally compelled remedies tracked that of Professors Fallon and Meltzer, who in 1991 published an influential article on the same topic that argued: (1) there should be a strong but not always unyielding presumption in favor of individually-effective relief for every constitutional violation; and (2) there must exist a sufficient scheme of available remedies to ensure that constitutional rights do not become nullities and that government officials remain answerable as a systemic matter to the demands of the law. See Richard H. Fallon, Jr. \& Daniel J. Meltzer, New Law, Non-Retroactivity, and Constitutional Remedies, 104 HARV. L. REV. 1731, 1787-91 (1991). Fallon and Meltzer explained that their aim in using a descriptive approach, rather than seeking to develop a purely normative theory, was "to achieve enhanced clarity of doctrinal understanding; we hope to further comprehension of what courts have done and continue to do, and of the presuppositions that undergird their pattern of decisions." Id. at 1737. In building upon Fallon and Meltzer's groundbreaking work, I used the same approach because I too hoped to rationalize unexplained but principled judicial behavior. See Greabe, supra note 166, at 859-60. I thus took the remedial status quo as a given and did not seek to engage, for example, Professor John 
Court has never explicitly rationalized-is in fact also normatively sensible. I will explain why shortly. But first, I provide an overview of the different ways courts treat claims for specific relief from ongoing constitutional injury and claims for substitutionary relief for wholly concluded constitutional violations.

In the context of constitutional litigation, specific remedies typically enable a rightholder to halt an ongoing (or avoid an imminent) deprivation of a life, liberty, or property interest protected by the Constitution. ${ }^{168}$ In this way, they seek to provide or restore to the rightholder the very same interest that the Constitution protects. ${ }^{169}$ Specific constitutional remedies include rulings nullifying unconstitutional statutes or rules under which coercive enforcement proceedings (such as criminal charges) are brought; rulings enjoining such proceedings in circumstances where the statute or rule authorizing the action cannot constitutionally be applied on the facts of the case; injunctions and declarations that operate to prohibit ongoing or imminent rights violations other than unconstitutional enforcement actions; the provision of access to a judicial officer through the Great Writ of habeas corpus (so long as Congress has not lawfully suspended its availability); just compensation for takings; and make-whole relief for the coercive collection of unconstitutional taxes, duties, or fees. ${ }^{170}$

Substitutionary remedies, in contrast, provide "something else" to the rightholder. ${ }^{171}$ The quintessential substitutionary remedy is a monetary damage award. In fact, remedies treatises sometimes speak as though money is the only form of

Harrison's originalist argument for a theory of constitutionally compelled remedies built on the "private right" remedial framework that existed in the nineteenth century. See, e.g., John Harrison, Jurisdiction, Congressional Power, and Constitutional Remedies, 86 GEO. L.J. 2513, 2516-17 (1998). For a fascinating exchange that captures the difference between the Fallon/Meltzer approach and that of Professor Harrison, compare id., with Daniel J. Meltzer, Congress, Courts, and Constitutional Remedies, 86 GEO. L.J. 2537, 2549-65 (1998).

168. See Greabe, supra note 8, at 905 \& n.133 (citing Colleen P. Murphy, Money as a "Specific" Remedy, 58 ALA. L. REV. 119, 126 (2006)). Of course, there are situations where specific remedies only formally halt the ongoing constitutional deprivation by declaring it unconstitutional. See, e.g., Brown v. Bd. of Educ. (Brown II), 349 U.S. 294, 301 (1955) (reaffirming the unconstitutionality of separating students by race in public education but requiring only that the defendant districts desegregate "with all deliberate speed"). In such situations, the effects of the unconstitutional custom or policy at which the judgment is directed may linger indefinitely.

169. See Greabe, supra note 8, at $905 \&$ n.133.

170. See id. at 909-10; see also Douglas Laycock, The Death of the Irreparable Injury Rule, 103 HARV. L. REV. 687, 696 (1990).

171. Greabe, supra note 8, at 905-06 (internal quotation marks omitted); see also Colleen P. Murphy, Money as a "Specific" Remedy, 58 ALA. L. REV. 119, 126 (2006). 
substitutionary remedy. ${ }^{172}$ And sure enough, courts do in fact sometimes vindicate constitutional rights through monetary damage awards. ${ }^{173}$ But in the context of constitutional litigation, two other substitutionary remedies are far more common. The first is the exclusion of evidence at trial when the evidence was obtained pursuant to a wholly concluded invasion of rights, such as a search that violated the defendant's Fourth Amendment rights or an interrogation that violated the defendant's Fifth Amendment rights. ${ }^{174}$ The second is the topic presently under examination: the vacatur or reversal of a lower court judgment when constitutional error-e.g., a failure to exclude evidence that the Constitution prohibited the jury from hearing-occurred during the judicial proceedings leading to the judgment. ${ }^{175}$

Notice that there tends to be a fundamental difference between the nature of the constitutional violations that ground claims for specific remedies and that of the violations that ground claims for substitutionary remedies. Situations permitting the imposition of specific remedies typically involve challenges to ongoing constitutional violations, which themselves are almost always rooted in unconstitutional government policies or customs-viz., unconstitutional statutes, rules, regulations, practices, broadly applicable understandings, or the decisions of those who function as government policymakers. ${ }^{176}$ Situations where only a substitutionary remedy is possible, in contrast, usually involve the wholly completed, discretionary actions of those persons to whom we necessarily entrust government power

172. See, e.g., JAMEs M. Fischer, Understanding REMEdies $§ 2.2$ (2d ed. 2006); Robert N. LEAVELl ET AL., Equitable ReMEdies, RESTITUtion AND DAMAgES 1 (7th ed. 2005) ("Substitutionary relief substitutes money for the specific relief.").

173. Courts sometimes award monetary damages against individuals who have misused federal power pursuant to the cause of action recognized in Bivens $v$. Six Unknown Named Agents of Fed. Bureau of Narcotics, 403 U.S. 388, 389 (1971), and against municipalities and individuals who have misused state power under 42 U.S.C. $\S 1983$. This complex area of law is summarized in Greabe, supra note 166, at 866-68, 881-84.

174. See Greabe, supra note 166, at 868-71, 884-85; see also Arnold H. Loewy, Police-Obtained Evidence and the Constitution: Distinguishing Unconstitutionally Obtained Evidence from Unconstitutionally Used Evidence, 87 MICH. L. REV. 907, 907-09 (1989).

175. See Greabe, supra note 166, at 871-72, 885-87; Ogletree, supra note 15, at 157.

176. See, e.g., Brown v. Plata, 563 U.S. 493 (2011) (addressing ongoing prison population overcrowding with a court-mandated population limit). Consider the practical barriers to getting to court to seek injunctive or declaratory relief responsive to an imminent or ongoing invasion of rights by an individual government actor-e.g., a police officer or prison guard-who is simply exercising the discretion required of all law enforcement officers and cannot plausibly be characterized as administering a specific custom or policy adopted by a government policymaker. For further discussion on specific remedies, see Greabe, supra note 8, at 911-12. 
and ask that it be exercised according to constitutional norms in variable and dynamic circumstances not specifically addressed by an applicable custom or policy. ${ }^{177}$

In the former context-that involving a challenge to a facially unconstitutional "law" (broadly construing that term) or a law that cannot constitutionally be applied in the circumstances presented - the Supreme Court has regarded a remedy precluding future application of the law as constitutionally required so long as it is sought by means of a justiciable and properly preserved claim brought in a proper forum. ${ }^{178}$ But in the latter context-that involving a post hoc request for relief responsive to the completed, discretionary conduct of one exercising government power with no concomitant request that an unconstitutional law be enjoined-the Court has authorized the withholding of remedies under doctrines such as the qualified-immunity doctrine, exceptions to the exclusionary rule, and (most pertinently) the various harmless-error principles discussed above in Part II.A. ${ }^{179}$

Although it has never so explained its actions, the Supreme Court has behaved sensibly in treating specific remedies to ameliorate ongoing constitutional violations-when sought by means of justiciable and properly preserved claims asserted in proper forums-as constitutionally necessary, while treating substitutionary remedies responsive to wholly completed constitutional wrongs as contingent and subject to being withheld in circumstances where their negative effect on the

177. See, e.g., Bivens, 403 U.S. at 395-97 (noting the availability of money damages after unconstitutional arrest and search). For further discussion on substitutionary remedies, see Greabe, supra note 8, at 910-11. The qualifier "usually" is necessary because it is possible to experience a violation of one's rights that, although concluded, is rooted in an unconstitutional custom or policy that remains ongoing when a remedy is sought. See id. at $911 \mathrm{n} .155$ (giving as examples claims addressed to wrongs rooted in an unconstitutional municipal custom or policy or in an unconstitutional sentencing guidelines regime). In such cases, the victim may seek both specific relief (a declaration that invalidates the legal regime that authorized the wrong) and a substitutionary remedy for the harm actually suffered.

178. See Greabe, supra note 8, at 917-19; see also, e.g., Plata, 563 U.S. at 526 (observing that it "would raise serious constitutional concerns" to read the Prison Litigation Reform Act of 1995 to foreclose a remedy for an ongoing unconstitutional prison overcrowding (citing Bowen v. Mich. Acad. of Family Physicians, 476 U.S. 667, 681 n.12 (1986))); id. at 502, 545 (observing that the ongoing constitutional violation of prison overcrowding "requires a remedy").

179. See, e.g., Harlow v. Fitzgerald, 457 U.S. 800, 818 (1982) (holding that "government officials performing discretionary functions, generally are shielded from liability for civil damages insofar as their conduct does not violate clearly established statutory or constitutional rights of which a reasonable person would have known.”). For further discussion on remedy-limiting doctrines, see Greabe, supra note 8, at 912-17. 
public interest would be too great. Specific remedies are more directly rooted in the text and structure of the Constitution than their substitutionary counterparts; they far more directly operationalize claims brought to enforce structural values such as federal supremacy, federalism, and the separation of federal powers into three branches, including a judicial department entrusted with judicial review. ${ }^{180}$ Indeed, the Constitution explicitly contemplates the specific remedies of access to a judicial officer through the Great Writ of habeas corpus, ${ }^{181}$ and the provision of just compensation for a taking. ${ }^{182}$ And the other specific remedies responsive to constitutional violations ${ }^{183}$ are easily seen as constitutionally necessary when we recall that they: (1) act to stop ongoing unconstitutional conduct at the lawmaking level (where the effects of the unconstitutional law are broadly applicable and likely to be experienced again and again by others); and (2) therefore serve as the means by which courts perform the quintessential function of judicial review, which is to keep the coordinate federal branches and the States within constitutional bounds. ${ }^{184}$

In contrast, substitutionary remedies for constitutional violations-money damage awards, the exclusion of evidence, and the vacatur or reversal of judgments because of a constitutional error at trial-lack any direct link to the text or structure of the Constitution. It is for this reason that substitutionary constitutional remedies are pervasively regarded as products of subconstitutional common law lawmaking ${ }^{185}$ _at least in circumstances where they are not statutorily authorized. ${ }^{186}$ By their very nature, they provide less narrowly tailored relief than specific remedies deliver, for they fail to prevent, halt, or undo the constitutional violations to which they respond. ${ }^{187}$ Moreover, they frequently engender significant and controversial costs that third parties who were not directly involved in the right-violating event must bear. ${ }^{188}$ To be sure,

\footnotetext{
180. See Greabe, supra note 8, at 921.

181. See U.S. ConsT. art. I, § 9, cl. 2.

182. See U.S. Const. amend. V.

183. See supra note 170 and accompanying text.

184. See Greabe, supra note 8, at 922 (citing Marbury v. Madison, 5 U.S. (1 Cranch) 137, 163, 177 (1803)).

185. See id. at 920 n.197 (collecting authority); see also Meltzer, supra note 8, at 26.

186. See, e.g., 42 U.S.C. $\$ 1983$ (2012) (authorizing monetary damage awards for constitutional violations).

187. See Greabe, supra note 8, at 920-21; cf. Herring v. United States, 555 U.S. 135, 141 (2009) (noting the efficacy of the exclusionary rule in deterring Fourth Amendment violations in the future).

188. See Greabe, supra note 8, at 921 (citing People v. Defore, 150 N.E. 585, 587
} 
substitutionary constitutional remedies are crucial mechanisms for ensuring adherence to constitutional norms; eliminating them without replacing them with effective alternatives would invite too much underenforcement of constitutional norms. But while they are integral to our constitutional order as a class, they also are properly regarded as individually contingent and susceptible to legislative or judicial expansion, contraction, or replacement as the perceived public interest dictates. ${ }^{189}$

The functional analysis I have just summarized brings us, with an important qualification, ${ }^{190}$ to the same conclusion reached by Professor Meltzer-viz., that the Chapman principle's implicit promise of relief in cases where the government fails to establish beyond a reasonable doubt the harmlessness of a constitutional trial error does not deliver a constitutionally compelled remedy. This conclusion (as qualified) serves as the foundational hypothesis for the rest of the paper. For if we accept that the Constitution ordinarily imposes no barrier to reform, we can proceed to consider whether the doctrines governing harmless-error review might in fact beneficially be reformed, and the paths any such reforms might take. Parts III and IV take up these questions. But before moving on, I address an argument that, if accepted, would undermine my hypothesis and preclude reform efforts of the type I propose.

Obviously, my hypothesis is built from a characterization of appeals and habeas petitions challenging constitutional trial

(N.Y. 1926) (Cardozo, J.) ("The criminal is to go free because the constable has blundered.”)).

189. See Greabe, supra note 166, at 893; see also Meltzer, supra note 167, at 2564-65 (noting that many of the concerns about negative effects on the public interest raised by actions for substitutionary relief against individual officers are not present in lawsuits to enjoin ongoing unconstitutional practices that might affect large numbers of individuals).

190. The qualification is that, when the claim is for specific relief from the ongoing application of a criminal statute that is facially unconstitutional or cannot constitutionally be applied, the reviewing court must afford relief. It is widely recognized that, when a court has jurisdiction and is faced with a justiciable, properly preserved, and meritorious claim of this sort, a remedy is constitutionally necessary. See, e.g., RICHARD H. FAllon, JR., ET Al., Hart AND Wechsler's The Federal Courts and the Federal SysteM 718 (6th ed. 2009); John C. Jeffries, Jr. \& George A. Rutherglen, Structural Reform Revisited, 95 CALIF. L. REV. 1387, 1391-92 (2007). Indeed, the Supreme Court has treated the obligation to provide relief responsive to this sort of claim as so obvious that it does not even list a trial court's failure to dismiss a prosecution brought pursuant to a facially unconstitutional law (or to a law that cannot constitutionally be applied) as "structural" error. See supra notes 79-85 and accompanying text. Rather, it simply provides relief without any further consideration of whether it should withhold a remedy under harmless-error doctrine. See, e.g., Lawrence v. Texas, 539 U.S. 558, 578-79 (2003) (reversing conviction based on facial unconstitutionality of statute under which prosecution was brought); Bond v. United States, 134 S. Ct. 2077, 2093-94 (2014) (reversing conviction because criminal statute could not constitutionally be applied on the facts of the case). 
errors committed by judges and prosecutors - other than review of the erroneous failure to dismiss a prosecution brought on the basis of a facially unconstitutional statute or a statute that cannot constitutionally be applied ${ }^{191}$ —as involving claims for a substitutionary remedy (the vacation or reversal of a judgment of conviction) responsive to isolated and wholly concluded constitutional wrongs (e.g., the admission of evidence that should have been excluded under the Self-Incrimination or Confrontation Clauses). But in a recent article, Professor Richard M. Re proposes a different characterization of the harm done when evidence is unconstitutionally admitted or excluded at trial. ${ }^{192}$ Re argues that, when a judgment of conviction is entered at the conclusion of a criminal trial marred by an unconstitutional evidentiary ruling, a second constitutional violation takes place - a deprivation of the defendant's liberty without due process. ${ }^{193}$ What's more, this second constitutional violation is ongoing from the moment the judgment of conviction is entered, and it requires a remedy as a matter of constitutional law when brought to the attention of a reviewing court unless the government is able to show that admission of the evidence was harmless beyond a reasonable doubt. ${ }^{194}$ In other words, the Chapman principle's implicit promise of relief unless the government establishes harmlessness beyond a reasonable doubt delivers a constitutionally compelled remedy responsive to an ongoing deprivation of the defendant's due process right not to be convicted at a trial where evidence that might have played a role in the decision to convict was unconstitutionally admitted. ${ }^{195}$

Re's call for recognition of such a due process right will be attractive to many who are concerned about the Supreme Court's recent expansion of remedy-withholding doctrines such as qualified immunity, exceptions to the exclusionary rule, and harmless error. ${ }^{196}$ But it is difficult to reconcile with the doctrines and practices that, at present, constitute the law of constitutional remedies. Most basically, such a right could be enforced only by means of a procedural mechanism that the Supreme Court

\footnotetext{
191. See supra note 190.

192. See Re, supra note 6, at 1912. In the article, Re's principal purpose is to argue that the Constitution's due process clauses require the exclusion at trial of evidence obtained pursuant to searches and seizures that violated the Fourth Amendment. See id. at 1887. I do not here engage this interesting and well-developed argument. Rather, I address only Re's comparatively brief suggestion that the due process clauses also require appellate courts to apply the Chapman principle.

193. See id. at 1912 .

194. See id. at 1915-17.

195. See id.

196. I count myself among their ranks. See Greabe, supra note 8, at 926-27.
} 
repeatedly has said is not constitutionally required-namely, appeal from a criminal judgment. ${ }^{197}$ Therefore, Re either must provide a reason why the Supreme Court's statements are wrong, or locate the right within some doctrine that places constitutional limits on the provision of constitutionally gratuitous procedures. ${ }^{198}$ Otherwise, the right would be singular among criminal constitutional trial rights in that there would be no constitutionally required process for its vindication. This would be powerful evidence of its nonexistence, given our constitutional commitment to requiring some procedural means for ameliorating an ongoing, individualized violation of constitutional rights. ${ }^{199}$

There are other reasons to doubt that one convicted at a trial in which material evidence was unconstitutionally admitted or excluded is suffering an ongoing constitutional violation separate and apart from the underlying admission or exclusion of evidence. The appellate judgment call that vindication of the right would entail only rarely would curb further application of a broadly applicable unconstitutional custom or policy that, if left unchecked, might potentially also deprive others of their rights. ${ }^{200}$ Rather, in most cases, such a judgment call simply would require an appellate court to decide on a unique set of facts whether the trial judge incorrectly failed to enforce a constitutional boundary and, if so, whether the trial judge's error was harmless. ${ }^{201}$ And the underlying trial court ruling-which at bottom is the constitutional actus reus that Re's due-process theory targets-is a quintessentially discretionary, point-in-time judgment call of a type that, if deemed erroneous by a reviewing court, does not require the provision of a remedy as a matter of constitutional law. ${ }^{202}$ Although the effects of such mistakes undoubtedly persist, we do not conceptualize the violations themselves as ongoing. We do not, in other words, understand the Constitution to promise a right to be free from detention after a trial in which ontologically "unconstitutional" evidentiary rulings have been handed down. Rather, we understand the Constitution to promise only a right to a trial in which an

\footnotetext{
197. See supra notes 139-145 and accompanying text.

198. See supra notes 156-164 and accompanying text. Re does not argue that there is a constitutional right to appeal or suggest that there is another ground for constitutionalizing the Chapman principle notwithstanding the absence of such a right.

199. See supra notes $178,180-184$.

200. See supra notes 177, 183-184 and accompanying text.

201. See id.

202. See supra notes 185-189 and accompanying text.
} 
unbiased and duly appointed judge will rule on constitutional challenges as they are raised.

Finally, prevailing principles governing the provision of remedies on collateral review are inconsistent with the argument that a person convicted of a crime after a material and constitutionally erroneous evidentiary ruling endures a separate, ongoing constitutional violation. A habeas court that disagrees with a state appeals court's determination that a constitutional trial error was harmless under Chapman does not simply grant the writ; rather, the court is under a mandate to accord an extra measure of deference and withhold a remedy unless the state appeals court's Chapman ruling was itself patently unreasonable. ${ }^{203}$ Such a remedy-withholding principle would not be possible if a habeas applicant with a meritorious claim that a state appellate court misapplied Chapman was seen to be presenting a claim for specific relief directed at an ongoing constitutional wrong-at least so long as courts continue to regard a remedy as constitutionally obligatory in such circumstances. ${ }^{204}$ We should be reluctant to begin recognizing exceptions to this foundational principle of constitutional remedies.

\section{Assessing The STATUs QUO: A NEED FOR REFORM}

The Supreme Court's major harmless-error decisions have not been models of clarity. As we have seen, Kotteakos suggested without explanation that its elaboration of how to apply the federal harmless-error statute would "perhaps" not apply to constitutional error even though the statute did not distinguish between constitutional and nonconstitutional error. ${ }^{205}$ Moreover, Chapman did not specify the source of the authority by which it

203. See supra notes 100-106.

204. That courts do regard a remedy as obligatory when an applicant for habeas relief presents a justiciable and properly preserved claim for relief directed at an ongoing constitutional violation may be seen in the doctrine of Teague v. Lane, 489 U.S. 288 (1989). Justice O'Connor's plurality opinion-which has subsequently been treated by the Court as controlling, see FALLON ET AL., supra note 190, at 1242, requires a habeas court to provide a remedy when the Supreme Court issues a "new rule" that makes previously punishable conduct constitutionally protected. See Teague, 489 U.S. at 307-10 (O'Connor, J., plurality opinion). This rule operationalizes the promise of relief for a truly ongoing constitutional violation in a context-collateral review-that is otherwise quite begrudging with respect to remedies.

205. See supra notes 30, 38-39 and accompanying text (discussing Kotteakos and setting forth the text of the federal harmless-error statute at the time Kotteakos was decided). Kotteakos also failed to explain why the error it was reviewing-a variance between the conspiracy charged in the indictment and the conspiracies proved at trialwas not of constitutional dimension. 
imposed its holding on state courts. ${ }^{206}$ And as we shall see, Fulminante adopted a jurisprudence of easily manipulated labels, Brecht recast Kotteakos in terms that bear little resemblance to the original, and the Court's more recent decisions about application of harmless-error analysis on collateral review appear to be animated more by a hostility towards collateral relief than a commitment to the principled application of precedent. Given this history, it is not surprising that the present state of harmless-error doctrine is unsatisfactory. This Part provides a critique of current doctrine that sets the stage for the reforms advocated in Part III.

\section{A. The "Privileging" of Constitutional Error}

In Chapman, the Supreme Court tacitly decided to "privilege" constitutional trial errors over nonconstitutional trial errors. ${ }^{207}$ It did so by instructing appellate courts to apply a stricter, "harmless beyond a reasonable doubt" standard-rather than the more forgiving Kotteakos "substantial and injurious effect or influence" standard (which the Chapman majority did not discuss) - in evaluating the harmlessness of constitutional trial errors. ${ }^{208}$ The Court took this action even though the federal harmless-error statute, 28 U.S.C. $§ 2111$, draws no distinction between constitutional and nonconstitutional errors. ${ }^{209}$

The Court has never attempted to rationalize its practice of privileging constitutional errors in the context of harmless-error review. The Court has not suggested, for example, that it requires constitutional privileging because it views parties challenging convictions as private attorneys general who help secure compliance with constitutional norms by judges and

\footnotetext{
206. See supra Part II.B.

207. I am indebted to Professor Michael Coenen for the term "constitutional privileging." See Coenen, supra note 11. Coenen's article presents a powerful, transcontextual argument urging skepticism towards constitutional privileging. Coenen considered and found wanting a number of arguments that might be made in favor of the practice based on either the perceived intrinsic preeminence of constitutional law, see id. at 712 , or, alternatively, possible extrinsic reasons for treating constitutional law as preeminent. See id. at 728-29. Coenen argued that one of the doctrinal areas that would benefit from elimination of constitutional privileging is harmless-error review. See id. at 741. I fully agree and, in Part IV, propose a reformed approach to harmless-error review that would eliminate the practice.

208. See supra notes 55-64 and accompanying text.

209. The statutory predecessor to $\S 2111,28$ U.S.C. $\S 391$, stated that courts should disregard "technical" errors that did not affect the substantial rights of the parties. Act of Feb. 26, 1919, ch. 48, 40 Stat. 1181, repealed by Act of June 25, 1948, ch. 646, § 39, 62 Stat. 892, 998. But there is no basis to conclude that Congress intended the statutory reference to "technical" errors to differentiate between constitutional and nonconstitutional errors.
} 
prosecutors. ${ }^{210}$ Rather, the Court appears simply to have assumed that mistakes of constitutional dimension are somehow more likely to have compromised the accuracy of the verdict than nonconstitutional errors. The assumption is unwarranted.

To understand why, consider the following passage from Justice Scalia's dissenting opinion in Webster $v$. Doe. ${ }^{211}$ Webster adopted constitutional privileging in a different context; it held that, under the Administrative Procedure Act, termination decisions by the Director of the Central Intelligence Agency under the National Security Act of 1947 were subject to constitutional but not statutory challenges. ${ }^{212}$ But Justice Scalia's dissenting argument makes a point that also rings true with respect to constitutional and nonconstitutional trial errors:

Perhaps ... a constitutional right is by its nature so much more important to the claimant than a statutory right that a statute which plainly excludes the latter [from judicial review] should not be read to exclude the former unless it says so. That principle has never been announced-and with good reason, because its premise is not true. An individual's contention that the Government has reneged upon a $\$ 100,000$ debt owing under a contract is much more important to him-both financially and, I suspect, in the sense of injustice that he feels-than the same individual's claim that a particular federal licensing provision requiring a $\$ 100$ license denies him equal protection of the laws, or that a particular state tax violates the Commerce Clause. A citizen would much rather have his statutory entitlement correctly acknowledged after a constitutionally inadequate hearing, than have it incorrectly denied after a proceeding that fulfills all the requirements of the Due Process Clause. ${ }^{213}$

So too with persons who were convicted after criminal trials that were marred by error. Surely, at least in ordinary circumstances, such persons are unlikely to care particularly about whether the error was rooted in the Constitution, a statute, or a rule of evidence or criminal procedure. Rather, the principal concern will

210. Compare, in this respect, the deterrence rationale underlying the Fourth Amendment's exclusionary rule. See, e.g., Davis v. United States, 131 S. Ct. 2419, 2426 (2011) ("The [exclusionary] rule's sole purpose, we have repeatedly held, is to deter future Fourth Amendment violations."). For criticism of the Court's single-minded focus on the accuracy of convictions in developing a harmless-error jurisprudence, see infra note 324.

211. 486 U.S. 592, 606-21(1988) (Scalia, J., dissenting).

212. See id. at 594 (discussing the National Security Act of 1947, 50 U.S.C. § 403(c) (1982) (current version at 50 U.S.C. § 3036(e)(1) (2006 \& Supp. I 2012)).

213. Id. at 618 (Scalia, J., dissenting). 
be with the error's likely prejudicial effect-i.e., how likely it is that the error played some role in the decision to convict.

Consider, for example, a criminal defendant whose federal jury trial on an indictment charging that he was a felon in possession of a firearm ${ }^{214}$ ends in conviction after the trial judge has committed two separate errors. First, the judge erroneously admitted into evidence, over the defendant's objection, a Trace Summary authored by an unknown employee of the federal Bureau of Alcohol, Tobacco, Firearms, and Explosives that tended to show that the firearm had traveled in interstate commerce. Admitting such evidence in this way violated the defendant's Sixth Amendment confrontation rights. ${ }^{215}$ Second, the judge, again over the defendant's objection, permitted the prosecution to introduce evidence of the defendant's extensive criminal history and to argue that such evidence tended to show both the defendant's bad character and the likelihood that he had committed the crime with which he was charged in accordance with that bad character, in violation of the Federal Rules of Evidence, rule 404(b)(1). ${ }^{216}$

Suppose further that, at trial, the defendant never contested the fact that the firearm in question had moved in interstate commerce. Rather, his defense was that the firearm had been planted on him and that he therefore had not knowingly possessed it. In such a situation, the defendant is going to be far more concerned about the Rule 404(b)(1) error than the Confrontation Clause error. Quite clearly, the Rule 404(b)(1) error is far more likely to have played a role in the jury's decision to convict. And yet, harmless-error principles instruct reviewing courts to be more parsimonious in providing a remedy for the Rule 404(b)(1) error. This makes no sense, particularly in view of the fact that the principles governing harmless-error review have never been justified in terms other than an error's putative effect on the verdict. ${ }^{217}$

214. 18 U.S.C. $§ 922(\mathrm{~g})(1)$ makes it unlawful for a person convicted of a crime punishable by imprisonment for a term exceeding one year to knowingly possess a firearm that has been shipped or transported in interstate commerce.

215. See United States v. Roberts, 419 F. App'x 155, 160-61 (3d Cir. 2011) (holding that the admission of a Trace Summary in such circumstances violates the Confrontation Clause).

216. Rule 404(b)(1) states: "Evidence of a crime, wrong, or other act is not admissible to prove a person's character in order to show that on a particular occasion the person acted in accordance with the character."

217. See William M. Landes \& Richard A. Posner, Harmless Error, 30 J. LEGAL Stud. 161, 172 (2001) (criticizing application of a stricter harmless-error test for constitutional errors on the ground that there is no basis for regarding constitutional errors as categorically more serious than nonconstitutional errors); see also TRAYNOR, supra note 1, 
There also are practical reasons to view skeptically the efficacy of the mandate that constitutional trial errors be assessed under the "stringent" Chapman principle while nonconstitutional errors be evaluated under the "less onerous" Kotteakos standard. ${ }^{218}$ Some of our most respected judges have opined that relatively slight variations in standards of review do not actually affect the outcomes of judicial decisions. ${ }^{219}$ In this respect, reread the explanation of how to apply the federal harmless-error statute Justice Rutledge provided in Kotteakos, ${ }^{220}$ compare it with the harmless-error analysis Justice Black prescribed in Chapman, ${ }^{221}$ and consider whether a faithful application of these supposedly distinct standards would lead to different outcomes in a nonnegligible number of cases. ${ }^{222}$ Many

at 48-49 (lamenting the complications caused by different tests for evaluating constitutional and nonconstitutional error and opining that a properly formulated and calibrated unitary test would naturally take into account the nature of the error in assessing whether it required a remedy).

218. See supra notes $96-97$ and accompanying text.

219. See, e.g., United States v. Lombard, 102 F.3d 1, 4-5 (1st Cir. 1996) (opinion of Boudin, Cir. J.) (expressing doubt that case outcomes are much affected by the imposition of a "clear and convincing evidence," rather than a "preponderance of the evidence," standard of proof); Richard A. Posner, Comment on Professor Gluck's "Imperfect Statutes, Imperfect Courts", 129 HARV. L. REV. F. 11, 14 (2015) (stating that, although appellate courts and law professors are forever "complexifying" law by purporting to apply a number of different standards of appellate review, "the only real as opposed to nominal difference is between plenary review, of pure issues of law, and mildly deferential review, of findings of fact and applications of legal doctrines to facts found by the lower court or agency"); $c f$. Jonathan S. Masur \& Lisa Larrimore Ouellette, Deference Mistakes, 82 U. CHI. L. REV. 643 (2015) (detailing how judges and their law clerks frequently confuse or ignore the "deference regime"-i.e., the standard of review or burden of proof that governs a case - of a given precedent and then proceed to misapply the precedent in a different context).

220. See supra note 38 and accompanying text (stating that an error is to be disregarded if "the conviction is sure that [it] did not influence the jury," but should not be disregarded "if one cannot say, with fair assurance, after pondering all that happened without stripping the erroneous action from the whole, that the judgment was not substantially swayed by the error" or "if one is left in grave doubt" whether the error "had substantial influence").

221. See supra notes 59-61 and accompanying text (stating that the error should not be disregarded if "there is a reasonable possibility that [it] might have contributed to the verdict" or if the reviewing court cannot "declare a belief that it was harmless beyond a reasonable doubt").

222. The Court's use of the descriptor "stringent" in connection with the Chapman principle and "less onerous" in connection with the Kotteakos/§ 2111 standard-provided as they were in the context of adopting a laxer standard for review of constitutional error on collateral review, see supra notes 96-97 and accompanying text-may well have been intended to signal lower courts to operationalize harmless-error review on habeas in a far more lenient manner than a fair reading of Kotteakos would imply. Certainly, the Court's subsequent treatment of the Kotteakos/§ 2111 standard on collateral review strongly suggests just such an intention. See infra Part II.C. But this only highlights another problem with the status quo of harmless-error review: that precedent is not to be taken at face value. 
commentators-including two Supreme Court Justices-have said that the answer is "no." 223 In fact, even within the more demanding realm of Chapman (and therefore certainly within the more lenient realm of Kotteakos), there is a pervasive sense that, too often, only one thing really matters to most judges and clerks when they read trial court records to assess whether an error was harmless: the strength of the evidence of guilt. As Anthony Amsterdam has put it:

In theory, the standard by which appellate courts are supposed to test the harmlessness of most constitutional errors in the pretrial process and at trial is whether the judges are convinced beyond a reasonable doubt that the error did not contribute to the guilty verdict or the sentence. But in practice, it much more often boils down to whether the appellate judges think that the prosecution's evidence of guilt was potent and the sentence well deserved.

... When appellate judges decide to reject a claim of error on harmless-error grounds, they very often do not say anything at all about the claim in their opinion. When they do say that the claim has been considered and rejected on harmless-error grounds, their explanation for why they regard any possible error as harmless is ordinarily brief and unrevealing, often conclusionary, almost always immune to criticism or review because it is case-specific and therefore opaque to anyone not thoroughly familiar with the record of the particular case. 224

Finally, there are grounds for questioning whether a violation of positive law occurring during the proceedings leading

223. Judge Harry T. Edwards of the U.S. Court of Appeals for the District of Columbia Circuit has stated that it is hard to discern any material difference between the Chapman principle and the Kotteakos/§ 2111 standard. Harry T. Edwards, To Err is Human, But Not Always Harmless: When Should Legal Error Be Tolerated?, 70 N.Y.U. L. REv. 1167, 1179 (1995); see also United States v. Dominguez Benitez, 542 U.S. 74, 86-87 (2004) (Scalia, J., concurring) (suggesting that the difference between the Chapman principle and the Kotteakos/§2111 standard involves an "ineffable gradation[] of probability" that is "quite beyond the ability of the judicial mind (or any mind) to grasp, and thus [is] harmful rather than helpful to the consistency and rationality of judicial decisionmaking"); Brecht v. Abrahamson, 507 U.S. 619, 643 (1993) (Stevens, J., concurring) (emphasizing the demanding nature of the Kotteakos/§ 2111 inquiry and stating that the difference between the Chapman principle and the Kotteakos/\$ 2111 standard is "less significant than it might seem"); Poulin, supra note 70, at 1013-15 (convincingly denouncing the impossibly fine and meaningless distinctions among the Supreme Court's various tests for harm in criminal cases).

224. Anthony G. Amsterdam, Remarks at the Investiture of Eric M. Freedman as the Maurice A. Deane Distinguished Professor of Constitutional Law, November 22, 2004, 33 HofstRA L. REV. 403, 405-06 (2004) (footnotes omitted). Professor Amsterdam's sense of how harmless-error review often proceeds in practice accords with my own, based on my thirteen years as a career law clerk to three different federal appeals court judges. 
to a criminal conviction-e.g., the admission of evidence that should have been excluded under the Federal Rules Evidence, rule 404(b)(1) in the hypothetical posited earlier in this subsection-ever should be regarded as "nonconstitutional" error. Notwithstanding the Supreme Court's recent reluctance to ascribe constitutional significance to violations of state and nonconstitutional federal law, many experts believe that the Constitution's due process clauses originally were understood to require adherence to all positive-law procedural rules applicable at criminal trials - or at least all positive-law procedural rules that function as part of the process for obtaining criminal convictions. ${ }^{225}$ And, of course, original meaning is dispositive for a number of members of the Court when it comes to setting the metes and bounds of the due-process guarantee. ${ }^{226}$

The scope of due process is one of the most contested topics in constitutional law, and there is no need to enter into the debate for present purposes. It is enough to say that the Court's use on direct review of two putatively different standards for assessing the harmlessness of violations of positive law at trialone applicable to "constitutional" violations and the other applicable to "nonconstitutional" error-almost certainly implies more about the nature of due process than some members of the Court intend to say. For this additional reason, it is time for the Court to stop differentiating between constitutional and nonconstitutional error in its harmless-error doctrines.

\section{B. The Structural Defect/Trial Error Dichotomy}

In Fulminante, the Supreme Court differentiated between a default category of "trial errors" amenable to harmless-error review and what has turned out to be a very small category of "structural defects" that require vacation or reversal of the affected conviction when it is challenged on direct review. ${ }^{227}$ Subsequently, in United States $v$. Gonzalez-Lopez, the Court described the latter category of error as one with effects that bear

225. See Re, supra note 6, at 1939-42 (citing, inter alia, Nathan S. Chapman \& Michael W. McConnell, Essay, Due Process as Separation of Powers, 121 YALE L. J. 1672, 1679 (2012); Ryan C. Williams, The One and Only Substantive Due Process Clause, 120 Yale L.J. 408, 420-21 (2010); John Harrison, Substantive Due Process and the Constitutional Text, 83 VA. L. REV. 493, 497 (1997); Edward J. Eberle, Procedural Due Process: The Original Understanding, 4 Const. CoMmENT. 339, 343 (1987)).

226. See, e.g., Obergefell v. Hodges, 135 S. Ct. 2584, 2611 (2015) (Roberts, C.J., dissenting); id. at 2626 (Scalia, J., dissenting); id. at 2631 (Thomas, J., dissenting); id. at 2640 (Alito, J., dissenting).

227. See supra notes 75-85 and accompanying text. 
"directly" on "the framework within which the trial proceeds." 228 But whether the Court believes that an error bears with sufficient directness on the trial framework to qualify as "structural" has proved to be no more predictable than whether the pre-1937 Court thought that activity bore with sufficient directness on interstate commerce to bring it within Congress's regulatory power. ${ }^{229}$ In other words, the Court's trial error/structural defect dichotomy has generated a results-driven jurisprudence of labels.

There is no shortage of criticism of the Fulminante framework, ${ }^{230}$ so I will not dwell on the subject at length. Instead, I will illustrate the unsatisfactory state of the Court's jurisprudence in this area by discussing the incoherent manner in which the Court has dealt with the questions of whether and how reviewing courts should review for harmlessness jury instructions that inaccurately describe, or fail to describe altogether, an element of a charged offense (instructions containing "elemental misdescriptions" or "elemental omissions"), or that direct the jury to presume that an element of the charged offense has been established by the trial evidence once it has found certain predicate facts (instructions setting up "mandatory presumptions"). ${ }^{231}$ Such instructions have the effect of permitting the jury to convict without having found each element of the offense charged beyond a reasonable doubt, as the Sixth Amendment jury-trial right and due process require. ${ }^{232}$

\footnotetext{
228. 548 U.S. 140, 150 (2006).

229. See, e.g., United States v. Lopez, 514 U.S. 549, 555 (1995) (describing how, in
} NLRB v. Jones \& Laughlin Steel Corp., 301 U.S. 1, 36-38 (1937), the Court "departed from the distinction between 'direct' and 'indirect' effects on interstate commerce" in favor of a more realistic analysis that asked whether regulated activities "have such a close and substantial relation to interstate commerce that their control is essential or appropriate to protect that commerce from burdens and obstructions").

230. See supra note 15 .

231. This terrain is covered in far more detail in Fairfax, supra note 15, at 2040-51, and Greabe, supra note 26, at 830-44.

232. See, e.g., United States v. Gaudin, 515 U.S. 506, 510 (1995) (noting the unconstitutionality of jury instructions that fail to require the jury to find an element of the crime charged); Sandstrom v. Montana, 442 U.S. 510, 520-24 (1979) (holding unconstitutional jury instructions that direct the jury to presume an element of the crime charged upon finding certain predicate facts regardless whether the presumption is conclusive or rebuttable); In re Winship, 397 U.S. 358, 364 (1970) (holding that "the Due Process Clause protects the accused against conviction except upon proof beyond a reasonable doubt of every fact necessary to constitute the crime with which he is charged"). An instruction setting up a conclusive (rather than a rebuttable) mandatory presumptioni.e., an instruction that requires the jury to make an elemental determination upon finding certain predicate facts-is unconstitutional for a second reason as well. It invades the jury's province by deterring it from considering any evidence relevant to the issue as to which the presumption is established but not relevant to the predicate factual findings that serve to 
On the one hand, the Court has long emphasized that a reviewing court should respect the jury's role as the fact finder and not hold an error harmless on the ground that it would have convicted had it been empaneled as the jury at the defendant's trial. ${ }^{233}$ This is why, in Sullivan v. Louisiana, the Court held that an inaccurate reasonable-doubt instruction is a structural defect impervious to harmless-error review. ${ }^{234}$ The question is not "whether, in a trial that occurred without the error, a guilty verdict would surely have been rendered, but whether the guilty verdict actually rendered in this trial was surely unattributable to the error." 235 Yet this is a meaningless question where the guilty verdict is based on an inaccurate instruction from the trial judge on the standard by which the jury is to judge guilt:

There being no jury verdict of guilty-beyond-a-reasonable -doubt, the question whether the same verdict of guilty beyond a reasonable-doubt would have been rendered absent the constitutional error is utterly meaningless. There is no object, so to speak, upon which harmless-error scrutiny can operate. The most an appellate court can conclude is that a jury would surely have found the petitioner guilty beyond a reasonable doubt-not that the jury's actual finding of guilty beyond a reasonable doubt would surely not have been different absent the constitutional error. That is not enough. The Sixth Amendment requires more than appellate speculation about a hypothetical jury's action, or else directed verdicts for the State would be sustainable on appeal; it requires an actual jury finding of guilty. ${ }^{236}$

If the Court were to apply this same line of reasoning to jury instructions containing elemental misdescriptions or omissions, and to jury instructions setting up mandatory presumptions, it would be compelled to conclude that such instructions also give rise to structural defects-at least in ordinary trial circumstances. After all, just like a defective reasonable doubt instruction, such an instruction ordinarily precludes the jury from returning a complete verdict rendered according to proper legal standards. The qualification "ordinarily" is necessary, however, because there might be situations where the improper

trigger the presumption. See Connecticut v. Johnson, 460 U.S. 73, 84-88 (1983) (plurality opinion)

233. See, e.g., Bollenbach v. United States, 326 U.S. 607, 614 (1946) ("[T]he question is not whether guilt may be spelt out of a record, but whether guilt has been found by a jury according to the procedure and standards appropriate for criminal trials . ...").

234. 508 U.S. 275, 281-82 (1993).

235. Id. at 279 (emphasis omitted).

236. Id. at 280 (emphasis added and citation omitted). 
instruction pertained only to an element of a crime of which the defendant was acquitted, where the defendant admitted to the element of the offense that was the subject of the improper instruction, or where the jury (after otherwise being properly instructed) made some other finding that necessarily also implied the "missing" finding. And, indeed, in Carella v. California, four members of the Court proposed that just such a three-part test be applied in reviewing for harmlessness jury instructions containing elemental misdescriptions or omissions, or setting up mandatory presumptions. ${ }^{237}$

On the other hand, the Supreme Court has resisted the logic of the argument described in the preceding two paragraphs and instead treated such instructions as giving rise to run-of-the-mill trial errors. In 1986, in Rose v. Clark, the Court held that jury instructions containing rebuttable mandatory presumptions are subject to ordinary harmless-error review. ${ }^{238}$ In 1987, in Pope $v$. Illinois, the Court extended the holding of Rose to jury instructions containing elemental misdescriptions. ${ }^{239}$ And in 1989, in Carella, the Court extended the holding of Rose to jury instructions containing conclusive mandatory presumptions. ${ }^{240}$ In all three cases, the Court avoided discussion of the tension between the Sixth Amendment's jury trial guarantee and application of harmless-error review to instructions containing errors which permit the jury to convict without actually having found each element of the offense charged—or without actually having made other findings that necessarily implied the missing finding - under the appropriate standard of proof. ${ }^{241}$

237. See 491 U.S. 263, 270-71 (1989) (Scalia, J., concurring in the judgment, joined by Justices Brennan, Marshall, and Blackmun).

238. 478 U.S. 570, 579-82 (1986) (implicitly rejecting the Court's plurality opinion in Connecticut v. Johnson, 460 U.S. 73 (1983), in which the Court had held that a conclusive mandatory presumption can only be harmless if the defendant was acquitted of the charge in question or if the defendant affirmatively conceded the issue on which the presumption was established). In 1991, in Yates v. Evatt, the Court followed Rose and reiterated that a rebuttable mandatory presumption may be harmless. See 500 U.S. 391, 402-11 (1991) (conducting harmless-error review and concluding that the error was not harmless beyond a reasonable doubt).

239. See 481 U.S. 497, 502-03 (1987).

240. Carella v. California, 491 U.S. 263, 266-67 (1989) (per curiam).

241. See Rose, 478 U.S. at 580-84 (stating that an instruction setting up a rebuttable mandatory presumption if the jury finds certain predicate facts may be harmless because the jury must still find the predicate facts and in many cases those predicate facts will conclusively establish the presumed element so that no rational jury could find the predicate facts without also finding the presumed element); Pope, 481 U.S. at 501-04 (stating that an instruction misdescribing an element of the offense may be harmless because the jury must still find the misdescribed element and it is possible that the tainted finding might conclusively establish the missing finding); Carella, 491 U.S. at 266-67 (stating that an instruction setting up a conclusive mandatory presumption if the 
Finally, in 1999, the issue came to a head in Neder $v$. United States. ${ }^{242}$ In Neder, the defendant was charged with a number of offenses including filing false income tax returns in violation of 26 U.S.C. $§ 7206(1) .{ }^{243}$ The district court, following then-binding circuit precedent, erroneously failed to instruct the jury to decide whether the false statements in the returns were material. ${ }^{244}$ The Court rejected the defendant's argument that the district court's mistake gave rise to a structural defect because it deprived the defendant of his Sixth Amendment jury-trial right in circumstances where he was not acquitted of the offense, where he did not admit materiality, and where the jury did not make other findings that necessarily implied a finding of materiality. ${ }^{245}$ The Court then held that this elemental omission was harmless error because the evidence of materiality was overwhelming and uncontested. ${ }^{246}$

In reaching this holding, the Court relied on Rose and its progeny which, as we have seen, held that appellate courts should conduct harmless-error review of instructional errors that have the effect of causing the jury not to make formally proper findings on each element of the offense charged.247 The Court also explicitly distanced itself from the analysis in Sullivan described in detail above. ${ }^{248}$ Instead, the Court narrowed Sullivan by stating that a mistaken reasonable doubt instruction gives rise to a structural defect only because it "vitiates all the

jury finds certain facts may be harmless because the jury must still find the predicate facts and in many cases those predicate facts will conclusively establish the presumed element). Rose alternatively suggested that "the jury would have found it unnecessary to rely on the presumption" because of overwhelming evidence of the missing element, and that such evidence also rendered the error harmless. See 478 U.S. at 583 (quoting Connecticut v. Johnson, 460 U.S. 73, 97 n.5 (1983) (Powell, J., dissenting)). But in Yates, the Court rejected this alternative line of reasoning and admonished reviewing courts that harmless-error review of instructions setting up rebuttable mandatory presumptions involves more than mere appellate inquiry into what a properly instructed jury likely would have concluded. See Yates v. Evatt, 500 U.S. 391, 406-07 \& n.11 (1991). As we shall see momentarily, however, the Court subsequently retreated from the more demanding analysis it insisted upon in Yates. See infra notes 250-251 and accompanying text.

242. 527 U.S. 1 (1999).

243. See id. at 6 .

244. See id. at 6-7 (noting that the trial took place before the Supreme Court's decision in United States v. Gaudin, 515 U.S. 506 (1995), which held that materiality in such cases must be determined by the jury).

245. See id. at 13-14.

246. See id. at 15-20.

247. See id. at 9-15.

248. See supra notes 233-236 and accompanying text. 
jury's findings and produces consequences that are necessarily unquantifiable and indeterminate." 249

The Court did not explicitly concede that its adoption of an "overwhelming evidence" test to govern review of elemental omissions was in logical conflict with another recent Court precedent. $^{250}$ Nor did it formally acknowledge that it was retreating from the Bollenbach principle. ${ }^{251}$ But, in response to Justice Scalia's blistering separate opinion, ${ }^{252}$ the Court all but admitted that its holding was outside the logic of its harmless-error precedents:

It would not be illogical to extend the reasoning of Sullivan from a defective "reasonable doubt" instruction to a failure to instruct on an element of the crime. But, as indicated in the foregoing discussion [of Rose and its progeny], the matter is not res nova under our case law. And if the life of the law has not been logic but experience, see O. Holmes, The Common Law 1 (1881), we are entitled to stand back and see what would be accomplished by such an extension in this case. The omitted element was materiality. Petitioner underreported $\$ 5$ million on his tax returns, and did not contest the element of materiality at trial. Petitioner does not suggest that he would introduce any evidence bearing upon the issue of materiality if so allowed. Reversal without any consideration of the effect of the error upon the verdict would send the case back for retrial-a retrial not focused at all on the issue of materiality, but on contested issues on which the jury was properly instructed. We do not think the Sixth Amendment requires us to veer away from settled precedent to reach such a result. ${ }^{253}$

This is a remarkable paragraph. On the surface, the Court's appeal to pragmatism is attractive. Remanding for a retrial in the circumstances described would seem to be the epitome of a mindless, logical formalism. But the passage ignores that the then newly minted legal regime the Court created in Fulminante to govern whether constitutional trial error is amenable to

\footnotetext{
249. Neder, 527 U.S. at 10-11 (citations, quotation marks, and ellipses omitted).

250. See supra note 241 (discussing Yates v. Evatt, 500 U.S. 391, 406-07 \& n.11 (1991)).

251. See supra note 233 and accompanying text.

252. See Neder, 527 U.S. at 30-39 (Scalia, J., concurring in part and dissenting in part) (endorsing Sullivan, of which he was the author, in very strong terms). Justices Souter and Ginsburg joined Justice Scalia's opinion. Id. Justice Stevens also wrote separately and disagreed with the majority's harmless-error analysis. See id. 25-27 (Stevens, J., concurring in part and concurring in the judgment).

253. Id. at 15 .
} 
harmless-error review ${ }^{254}$ calls for a logical and formalist analysis, and not a pragmatic and realistic one. Fulminante instructs that errors causing structural defects in the constitution of the trial mechanism defy analysis by harmless-error standards and require automatic reversal. ${ }^{255}$ And Sullivan instructs that a verdict from a properly instructed jury is essential to the constitution of the trial mechanism within the meaning of Fulminante. ${ }^{256}$ If the Neder majority thought the Fulminante regime to be too constraining, it should have said so explicitly. It should not have pretended that its decision was consistent with that regime. The Fulminante framework, like the Chapman principle that it serves to elaborate, is constitutional common law. ${ }^{257}$ And as with other common law doctrines, it should explicitly evolve if and when its shortcomings become apparent.

In United States v. Gonzalez-Lopez, Justice Alito authored a dissenting opinion, joined by Chief Justice Roberts and Justices Kennedy and Thomas, in which he sought to recast Fulminante in a way that would make the Neder decision more defensible when viewed in the light of Fulminante and Sullivan. ${ }^{258}$ Justice Alito wrote:

The majority's focus on the "trial error"/"structural defect" dichotomy is misleading. In Fulminante, we used these terms to denote two poles of constitutional error that had appeared in prior cases; trial errors always lead to harmless-error review, while structural errors always lead to automatic reversal. We did not suggest that trial errors are the only sorts of errors amenable to harmless-error review, or that all errors affecting the framework within which the trial proceeds are structural. The touchstone of structural error is fundamental unfairness and unreliability. Automatic reversal is strong medicine that should be reserved for constitutional errors that always or necessarily produce such unfairness. ${ }^{259}$

The majority responded by stating:

The dissent criticizes us for our trial error/structural defect dichotomy, asserting that Fulminante never said that trial

\footnotetext{
254. See Arizona v. Fulminante, 499 U.S. 279, 309-12 (1991). Note that Neder was decided in 1999 and Fulminante was decided in 1991. Chief Justice Rehnquist authored each opinion.

255. Id. at 309-10.

256. Sullivan v. Louisiana, 508 U.S. 275, 281-82 (1993).

257. See supra Part II.B.

258. 548 U.S. 140, 150 (2006) (holding that denial of counsel of one's choice is structural error not subject to review for harmlessness).

259. Id. at 159 (Alito, J., dissenting) (citations and internal quotation marks omitted).
} 
errors are the only sorts of errors amenable to harmless-error review, or that all errors affecting the framework within which the trial proceeds are structural. Although it is hard to read that case as doing anything other than dividing constitutional error into two comprehensive categories, our ensuing analysis in fact relies neither upon such comprehensiveness nor upon trial error as the touchstone for the availability of harmless-error review. Rather, here, as we have done in the past, we rest our conclusion of structural error upon the difficulty of assessing the effect of the error. ${ }^{260}$

The majority is correct; it is difficult to read Fulminante in the manner proposed by the Gonzalez-Lopez dissent. And yet, the dissent's impulse to abandon the formalistic Fulminante framework is sound. The costs of applying the Fulminante framework rigorously and faithfully are simply too high to bear. ${ }^{261}$ Moreover, commentators have persuasively argued, Fulminante's requirement that structural errors be automatically reversed has had the negative collateral consequence of causing lower courts to define structural rights too narrowly. ${ }^{262}$ The Court therefore should abandon the Fulminante framework in favor of a more realistic and pragmatic approach to harmless-error review. But it should do so explicitly, and not through precedential subterfuge of the sort displayed in Neder.

260. Id. at 149 n.4 (majority opinion) (citations and internal quotation marks omitted).

261. The Court's unwillingness to abide by Fulminante is not only evident in its decisions addressed to review of instructional error that causes the jury not to find each element of the offense charged under the proper legal standard. Other errors that seem "structural" - or at the very least seem not to be "quantitatively assess[able] in the context of the other evidence presented" and therefore not susceptible to harmless-error analysis, Arizona v. Fulminante, 499 U.S. 279, 307-08 (1991) (describing "trial errors" that are subject to harmless-error review) - that the Court recently has subjected to harmless-error review include improper judicial involvement in plea negotiations, United States v. Davila, 133 S. Ct. 2139, 2149 (2013); improper denial of a state-provided peremptory challenge, Rivera v. Illinois, 556 U.S. 148, 160-61 (2009); and the failure to submit to the jury a sentencing factor that the jury should have decided, Washington v. Recuenco, 548 U.S. 212, 218-22 (2006).

262. See Coenen, supra note 15, at 1235-39; Levinson, supra note 15, at 891-92; Shephard, supra note 15, at 1185-1205; Karlan, supra note 15, at 2021. Precedent containing an overly narrow definition of a right can then, in turn, wreak havoc when it is applied in other remedial contexts. See Coenen, supra note 15, at 1235-39 (noting that the high costs of automatic reversal at the appellate level cause appellate courts to set high precedential standards for trial courts to meet to order a reversal, although it is much less costly to cure these errors at the trial level than at the appellate level). 


\section{Recent Habeas Cases}

In its 1993 Brecht v. Abrahamson decision, the Supreme Court decided to abandon the "stringent" Chapman principle for a "less onerous" test for evaluating the harmfulness of constitutional error challenged on collateral review. ${ }^{263}$ The Court justified its action by pointing to the state's interest in the finality of convictions that had survived direct review, comity, federalism, the interest of maintaining the prominence of the trial itself (which often had taken place years earlier), the difficulty of retrials years after the original trial, and a perceived imbalance between other costs and benefits of continuing to apply Chapman on habeas. ${ }^{264}$ Since Brecht, the Court has become even more demanding in its descriptions of what habeas petitioners must show in order to establish harm and secure collateral relief for convictions tainted by constitutional error. ${ }^{265}$

This change in the law of harmless-error review has been, if not popular among civil libertarians and others who desire closer federal oversight of state criminal processes, certainly defensible. Retrying a successful habeas petitioner years after the original conviction is difficult, given the erosion of memory and the dispersion of witnesses, ${ }^{266}$ and the other reasons Chief Justice Rehnquist, the author of Brecht, provided in support of its holding also are far from trivial. Unfortunately, however, Brecht and its progeny have worked their change-part of a decades-long transformation of habeas from a regime preoccupied with the vindication of federal rights into a regime principally concerned with whether petitioners are guilty or innocent ${ }^{267}$ through a treatment of precedent that has shown insufficient regard for rule-of-law values.

Consider, first, Brecht's treatment of Kotteakos, ${ }^{268}$ which Brecht purported to adopt as the new standard for evaluating whether constitutional trial error had been harmless on

\footnotetext{
263. See supra notes 93-99 and accompanying text.

264. Brecht v. Abrahamson, 507 U.S. 619, 635-37 (1993). For further discussion on Brecht, see supra notes 89-99 and accompanying text.

265. See supra notes 102-111 and accompanying text.

266. See Brecht, 507 U.S. at 637.

267. For an excellent account of this shift and an argument that a new movement towards greater regard for procedural interests may be underway, see generally Justin F. Marceau, Is Guilt Dispositive? Federal Habeas After Martinez, 55 WM. \& MARY L. REV. 2071 (2014).

268. Recall that Kotteakos contained an elaboration of how to apply 28 U.S.C. $\S 391$, the statutory predecessor to the present harmless-error statute, 28 U.S.C. $\S 2111$. See supra notes 34-39 and accompanying text.
} 
collateral review. ${ }^{269}$ Recall again how, in Kotteakos, the Court was at pains to emphasize that harmless-error analysis must look to the likely effect of the error on the jury, and not be based on the reviewing court's opinion whether the jury likely would have convicted had the error not occurred. ${ }^{270}$ Indeed, as we have just seen, a careful reading of Justice Rutledge's Kotteakos opinion has caused many commentators-including some Supreme Court Justices-to question whether the analysis Kotteakos prescribes materially differs from that required by Chapman. ${ }^{271}$ In any event, clearly, Kotteakos does not say or intimate that an error is to be held harmless if the defendant fails to show that he likely would have been acquitted but for the error.

Brecht badly mischaracterizes Kotteakos in adopting it as the harmless-error standard to govern collateral review. Brecht contains no admonition against using the likelihood of conviction absent the error as a proxy for harmlessness. Nor does it say anything about how Kotteakos emphasized the need to keep the focus on whether the error likely affected the jury. Instead, Brecht says that the Kotteakos standard requires a habeas petitioner to show-Brecht summarily places the burden of persuasion on the petitioner despite Kotteakos's indication that the burden should lie with the government when the error is nontechnical 272 -more than just a "reasonable possibility" that the error contributed to the verdict. ${ }^{273}$ But this "reasonable possibility" language does not come from Kotteakos; indeed it is patently in tension with what Justice Rutledge says in explaining how courts are to determine whether an error should be treated as harmless. ${ }^{274}$ Rather, it is reverse engineered from a passage in Chapman indicating that an error is not harmless if there is a "reasonable possibility" that it "might have contributed to the conviction." 275 Thus, a blatant logical fallacy underlies Brecht's adoption of a more-than-a-reasonable-possibility standard:

\footnotetext{
269. See supra notes 96-99 and accompanying text.

270. See supra note 38 and accompanying text.

271. See supra note 223 and accompanying text.

272. Kotteakos v. United States, 328 U.S. 750, 765-66 (1946).

273. Brecht v. Abrahamson, 507 U.S. 619, 637 (1993) (internal quotation marks omitted). For further discussion on Brecht, see supra notes 89-99.

274. See Kotteakos, 328 U.S. at 765 ("But if one cannot say, with fair assurance, after pondering all that happened without striping the erroneous action from the whole, that the judgment was not substantially swayed by the error, it is impossible to conclude that substantial rights were not affected.") For Justice Rutlege's full explanation, see supra note 38 and accompanying text.

275. Chapman v. California, 386 U.S. 18, 23 (quoting Fahy v. Connecticut, 375 U.S. 85, 86-87 (1963) (internal quotation marks omitted).
} 
Brecht posits (dubiously, as we have seen) ${ }^{276}$ that the Kotteakos standard is appreciably more forgiving of error than the Chapman standard, observes that Chapman requires a remedy if there is a "reasonable possibility" that the error "might have contributed to the verdict," 277 and infers from this requirement of Chapman the logically faulty conclusion that Kotteakos requires more than such a reasonable possibility. ${ }^{278}$

Even more tenuously, Brecht then uses the phrase "actual prejudice" to describe the more-than-a-reasonable-possibility showing that, Brecht says, Kotteakos requires for an applicant to obtain a remedy. ${ }^{279}$ But again here, the phrase "actual prejudice" does not appear in Kotteakos; it comes from United States $v$. Lane, a 1986 decision authored by Chief Justice Burger that used the phrase without citation in purporting to apply Kotteakos to find that a misjoinder of criminal defendants under Federal Rules of Criminal Procedure, rule $8(b)^{280}$ had been harmless. ${ }^{281}$ More importantly, it is a component of what petitioners seeking to establish ineffective assistance of counsel ordinarily must show in order to establish a constitutional violation. ${ }^{282}$ And in that context, it means showing a "reasonable probability" of a different outcome but for the error. ${ }^{283}$ Thus, Brecht effectively signals that a habeas petitioner must establish a "reasonable probability" of nonconviction but for the error-a showing that is far more onerous than the one Justice Rutledge prescribed in Kotteakos. ${ }^{284}$ This signal was reinforced by Brecht's application of Kotteakos in its brief explanation of why the error at petitioner's trial had been harmless. Brecht focused heavily on the evidence

\footnotetext{
276. See supra notes 220-224 and accompanying text.

277. Brecht, 507 U.S. at 637.

278. See id. It is of course logically possible for the two standards to differ appreciably and yet for both to support a conclusion that there has been harm if there is a reasonable possibility that the error contributed to the verdict.

279. Brecht, 507 U.S. at 637(internal quotation marks omitted).

280. Rule 8(b) states:

The indictment or information may charge 2 or more defendants if they are alleged to have participated in the same act or transaction, or in the same series of acts or transactions, constituting an offense or offenses. The defendants may be charged in one or more counts together or separately. All defendants need not be charged in each count.

281. See United States v. Lane, 474 U.S. 438, 446-49.

282. See, e.g., Roe v. Flores Ortega, 528 U.S. 470, 481-82 (2000) (observing that, when a criminal defendant alleges that his or her attorney's performance during a legal proceeding, either at trial or on appeal, was constitutionally ineffective, the defendant ordinarily must establish "actual prejudice").

283. See id. at 482. (emphasis added) (defining "actual prejudice" as "a reasonable probability that, but for counsel's unprofessional errors, the result of the proceeding would have been different" (quoting Strickland v. Washington, 466 U.S. 668, 694 (1984)).

284. See supra note 38 and accompanying text.
} 
of guilt, and said nothing about the likelihood of the error playing a role in the jury's decision to return a guilty verdict. ${ }^{285}$

The Court's more recent decisions addressing the standard for harmless error on collateral review continue the practice of applying precedent in a disingenuous manner. As explained above, in 1996 (three years after Brecht), Congress enacted $\S 2254(\mathrm{~d})(1)$ of the AEDPA, which bars habeas relief for errors of law unless the error involved an unreasonable application of Supreme Court precedent. ${ }^{286}$ In 2003, in Mitchell v. Esparza, the Court held that $§ 2254(\mathrm{~d})(1)$ bars habeas relief for constitutional error that was held harmless under Chapman by a state appellate court unless that court's application of Chapman was unreasonable. ${ }^{287}$ Then, in 2007, in Fry v. Pliler, the Court rejected an argument that $\S 2254(\mathrm{~d})(1)$, as interpreted in Esparza, had effectively superseded Brecht. ${ }^{288}$

In describing the petitioner's argument as "implausible" and reaffirming the continuing applicability of Brecht, Justice Scalia (the author of Fry) characterized Brecht's "actual prejudice" standard as stricter than Esparza's "more liberal AEDPA/Chapman standard, which requires only that the state court's harmless-beyond-a-reasonable-doubt determination be unreasonable." 289 In fact, Fry says, Brecht "obviously subsumes the [more liberal AEDPA/Chapman standard]." ${ }^{290}$ Thus, through this reinterpretation of Brecht, Fry effectively transforms Kotteakos-which, again, Brecht purports to adopt-into a standard that requires a habeas petitioner now to show something more than that no reasonable jurist could find the error harmless under Chapman. To borrow from the rhetorical style of Fry's author: When one reads Justice Rutledge's Kotteakos opinion ${ }^{291}$ and compares it with what Fry implies about its contents, one quickly comes to realize that we have entered The Land of Make-Believe.

While Fry, through its treatment of Brecht, effectively catapulted the Kotteakos standard past the point where it might reasonably be described as merely "permissive" or "forgiving" of error-perhaps "hippie-parent indulgent" would come closer to

\footnotetext{
285. See supra note 99 and accompanying text.

286. See supra notes 17, 100-101 and accompanying text.

287. See supra note 102 and accompanying text.

288. See supra note 103 and accompanying text.

289. Fry v. Pliler, 551, U.S. 112, 119-20 (2007) (emphasis added); see also supra notes 104-105 and accompanying text.

290. Fry, 551 U.S. at 120 (emphasis added); see also supra note 106 and accompanying text.

291. See supra note 38 and accompanying text.
} 
doing it justice-Davis v. Ayala, decided in 2015, sought to dispel any misperception that the "more liberal" AEDPA/Chapman standard is in fact petitioner-friendly. As we have just seen, Fry stated that Brecht (and thus Kotteakos) "subsumes" the AEDPA/Chapman standard described in Esparza. In recognition of the logical rule that satisfaction of a more demanding burden of persuasion always will constitute satisfaction of a less demanding burden of persuasion when the former subsumes the latter, ${ }^{292}$ Fry also acknowledged that there is no reason to require formal application of both tests. ${ }^{293}$

Nonetheless, Justice Alito (author of the Ayala majority opinion) criticized the Ninth Circuit for declining to perform the logically unnecessary analysis of whether the state court's harmlessness determination under Chapman was itself reasonable. ${ }^{294}$ Concluding that the state appellate court had not unreasonably applied Chapman, Ayala made it very clear that satisfying the putatively "more liberal" AEDPA/Chapman standard is not to be a walk in the park. To prevail under this standard, petitioners must show that "fair-minded jurists could [not] disagree on [the] correctness" of the state appellate court finding that a challenged error was harmless under Chapman. ${ }^{295}$ Put another way, habeas petitioners must establish that the state appellate court's decision "was so lacking in justification that there was an error well understood and comprehended in existing law beyond any possibility for fair-minded disagreement."296 Thus, given the holding in Fry, habeas petitioners now apparently must make some unspecified showing beyond this in order to establish that constitutional error was harmful within the meaning of Brecht/Kotteakos. ${ }^{297}$ One simply

292. Similarly, a failure to satisfy a less demanding burden of persuasion always will constitute a failure to satisfy a more demanding burden of persuasion when the latter subsumes the former.

293. Fry, 551 U.S. at 120; see also supra note 106 and accompanying text.

294. Ayala v. Davis, 135 S. Ct. 2187, 2198 (2015). For further discussion of criticism of lower courts' application of Fry, see supra notes 107-108 and accompanying text. Conducting the AEDPA/Chapman analysis prescribed in Esparza was logically unnecessary because the Ninth Circuit, in a divided panel opinion, concluded that the petitioner had satisfied the more demanding Brecht test. See Ayala, 135 S. Ct. at 2196-97.

295. Ayala, 135 S. Ct. at 2199 (internal quotation marks omitted).

296. Id.

297. To be sure, the Court continues to describe the Brecht/Kotteakos test as requiring a showing of "actual prejudice." Id. As we have seen, "actual prejudice" is a phrase that does not come from Kotteakos, but that in other contexts requires showing a reasonable probability of nonconviction but for the error. See supra notes 279-284 and accompanying text. But it is not at all evident how the "actual prejudice" test can be described as more demanding than the AEDPA/Chapman test that it is said to subsume. The "actual prejudice" test is entirely different in kind from the AEDPA/Chapman test. It 
cannot read Justice Rutledge's opinion and maintain that this is a principled distillation of Kotteakos.

Again, my purpose is not to quarrel with the Court's adoption of a very tough standard for establishing the harmfulness of error on collateral review. Perhaps the standard the Court has adopted is appropriate in view of the factors it cited in Brecht for moving away from Chapman. ${ }^{298}$ But, I submit, institutional damage is done when the Court purports to root its new standard in precedent that says nothing of the sort. Brecht and its progeny are constitutional common law-a type of law that, again, is supposed to evolve as data and experience reveal a need for change. The Court should be forthright about the fact that it perceived a need for change. It should not pretend that its recent holdings are anchored in precedent that not only do not say what they are cited for saying, but actually say something close to the opposite. The Court invites cynicism and undermines its reputation as an institution guided by principle when it behaves in this way.

\section{SUGGESTED REFORMS}

Part I demonstrates that Congress and the Supreme Court are largely unconstrained by constitutional limitations in fashioning harmless-error doctrines to govern on direct and collateral review. Part II shows that there is a serious need for doctrinal reform in both contexts. Part III seeks to initiate a discussion about the paths that reform might take. Most of this Part's suggestions for reform flow naturally from arguments developed in Parts I and II. To the extent that they press beyond the foundation laid earlier in the paper, they are preliminary and designed to provoke thought and, hopefully, conversation about how the present approach to harmless-error review might be improved.

\footnotetext{
looks at the likelihood of a different result had the trial error not occurred, while the AEDPA/Chapman test focuses on whether appellate judges reasonably could conclude that the error was harmless under Chapman. Ayala, 135 S. Ct. at 2197-99 (explaining the different requirements of each test). The two tests are not logically interrelated; they are apples and oranges.

298. Brecht v. Abrahamson, 507 U.S. 619, 635-37 (1946) (emphasizing the finality of convictions, comity, federalism, the interest of maintaining prominence of the trial itself, the difficulty of retrials years after the original trial, and a perceived imbalance of other costs and benefits of applying Chapman on collateral review); see also supra note 98 and accompanying text.
} 


\section{A. The Constitution \& the Path to Reform}

As Part I shows, the Constitution requires reviewing courts to vacate or reverse convictions marred by constitutional error only in circumstances where the applicant for relief establishes that the statute underlying the conviction is unconstitutional on its face or cannot constitutionally be applied to the facts of the case. 299 Beyond this, harmless-error analysis may proceed without constitutional constraint except that, of course, it may not be arbitrary or otherwise violate the equal-protection guarantee or the unconstitutional conditions doctrine. ${ }^{300}$

Importantly, this means that the Constitution does not forbid appellate courts or courts conducting collateral review from excusing errors that have resulted in missing jury findings or other structural defects, or even from adopting a harmless-error analysis that turns on nothing more than whether the error likely caused an innocent person to be wrongfully convicted of a crime. Transforming harmless-error analysis into mere prediction about likely innocence based on a cold appellate record would be a regrettable development, but it would not violate the Constitution.

\section{B. A Unitary Standard (and Abandoning Chapman)}

As Part II.A shows, there is no reason to privilege constitutional errors by subjecting them to a different harmless-error test than that applied to "nonconstitutional" errors. There are at least three reasons for stopping the practice. First, there is no basis for concluding that, as a class, errors that the Court describes as "constitutional" always tend to work a greater harm on criminal defendants than those labeled "nonconstitutional." 301 Second, there is reason to doubt that judges and their clerks can and do make the fine distinctions required between a faithful application of Chapman to constitutional error and a faithful application of Kotteakos to nonconstitutional error. ${ }^{302}$ Third, there is a serious argument to be made that all infractions of the positive law that governs criminal trials are "constitutional" in that they violate the due-process guarantee, which (it may plausibly be argued) requires compliance with all procedural requirements that

\footnotetext{
299. See supra note 190 and accompanying text.

300. See supra notes 156-160 and accompanying text.

301. See supra notes 207-217 and accompanying text.

302. See supra notes 218-224 and accompanying text.
} 
materially inform the process for obtaining criminal convictions. ${ }^{303}$

What, then, should the unitary standard be for evaluating errors amenable to harmless-error review? ${ }^{304}$ In my view, the approach for which Justice Traynor argued in the immediate aftermath of Chapman does the best job of legitimizing and rationalizing harmless-error doctrine, and of prescribing a remedial regime that American appellate judges might actually administer faithfully. Traynor called for rooting the harmless-error standard in 28 U.S.C. $\$ 2111^{305}$ and construing the statute to direct reviewing courts to provide a remedy unless there is a "high probability" that the error did not affect the jury's judgment. ${ }^{306}$

The merits of moving away from a standard based in constitutional common law (the most plausible understanding of Chapman's ontology ${ }^{307}$ ) and anchoring harmless-error review in $\S 2111$, the federal harmless-error statute, are straightforward. While constitutional common law is pervasive, there are many who contest its legitimacy. ${ }^{308}$ One need not align oneself with the critics of constitutional common law in order to see it as preferable to ground remedial doctrines in legislation that is perfectly constitutional and that reasonably can be construed to govern the problem under examination. ${ }^{309}$ Indeed, Chapman

303. See supra notes 225-226 and accompanying text.

304. I leave to the next subsection consideration of whether there should be errors not subject to harmless-error review.

305. See TRAYNOR, supra note 1, at 42-43. As Professor Meltzer argued, it is a stretch to treat Chapman as an elaboration of $\$ 2111$, given all that it contains and mandates. See supra notes 131-132 and accompanying text. But if the Court were to jettison Chapman, there is no reason why $\S 2111$ should not be held to govern the federal harmless-error field, notwithstanding the fact that it textually describes only those errors that reviewing courts should disregard. See supra note 9. If we can infer a "negative" or "dormant" commerce clause doctrine from constitutional text that in terms confers only a power to regulate, surely we can infer from statutory text admonishing courts to withhold remedies for a certain class of errors a directive that they continue to provide remediesin accordance with customary practice at the time the statute was adopted, see supra Part II.A-for errors that do not fall within the specified class.

306. See TRAYNOR, supra note 1, at 43-51.

307. See supra Part II.B.

308. See, e.g., Thomas W. Merrill, The Common Law Powers of the Federal Courts, 52 U. CHI. L. REV. 1, 58-59 (1985); Thomas S. Schrock \& Robert C. Welsh, Reconsidering the Constitutional Common Law, 91 HARV. L. REV. 1117 (1978). For a summary of an argument that remedial doctrines designed to address constitutional violations ought to originate with Congress, see ERWIN CHEMERINSKY, FEDERAL JURISDICTION § 9.1.2, at 652 (7th ed. 2016) (describing the dissenting opinions in Bivens v. Six Unknown Agents of Fed. Bureau of Narcotics, 403 U.S. 388 (1971)).

309. See supra note 305 and accompanying text. One might object that 28 U.S.C. $\S 2111$ is inadequate to supplant Chapman because it does not in terms directly regulate state courts, as Chapman does. In fact, the text of $\S 2111$ could be read to regulate state 
itself recognized congressional prerogative to replace its beyond-a-reasonable-doubt principle with an "appropriate" statutory standard. 310 Mysteriously, however, Chapman did not even mention $\S 2111$, let alone explain why an "appropriate" standard could not be distilled from it.

In fact, as Traynor demonstrated, $\S 2111$ is cast in general terms that are reasonably subject to translation into an "appropriate" and administrable harmless-error standard. The statute plausibly could be construed to give rise to at least three formulations that would accord with commonly applied proof standards: a test focusing on whether it was more probable than not that the error did not affect the jury (which would accord with the preponderance-of-the-evidence standard); a test focusing on whether it was highly probable that the error did not affect the jury (which would accord with the clear-and-convincing -evidence standard); and a test focusing on whether it was almost certain that the error did not affect the jury (which would accord with the beyond-a-reasonable-doubt test that Chapman did in fact adopt). ${ }^{311}$ Thus, there is no barrier to the Court grounding a new, unitary harmless-error standard in § 2111.

After surveying the range of standards through which $\S 2111$ might reasonably be operationalized, Traynor argued that the Court should adopt the second, "highly probable" test-one that would accord with the clear-and-convincing evidence standard. ${ }^{312}$ Traynor regarded the first, "more likely than not" test as inappropriate for two reasons: it would entail too great a risk of affirming judgments influenced by error, and it would tacitly invite reviewing courts to affirm whenever they believed that the jury had reached the correct result. ${ }^{313}$ He thought that the third,

courts. See supra note 9. And surely, if the Supreme Court can regulate the state courts through constitutional common law as it did in Chapman, it also would be within Congress's power to regulate directly the provision of remedies for constitutional violations that occur in state criminal trials. In any event, even if $\S 2111$ is (more plausibly) read only to regulate federal courts, it clearly regulates the Supreme Court, which of course has jurisdiction to review how state appellate courts administer remedies for violations of federal law during state criminal trials. Because state appellate courts ought to recognize the primacy of any harmless-error standard that Congress might lawfully require the Supreme Court to use to review their treatment of federal trial error, the effect of such congressional regulation of the Supreme Court should be a de facto imposition of the statute's harmless-error standard on state appellate courts.

310. See Chapman v. California, 386 U.S. 18, 21 (1967).

311. See TRAYNOR, supra note 1 , at 33-37, 42-51.

312. See id. at 45 .

313. See id. at 35. I fully agree with Traynor's assessment of the first test. Even under the beyond-a-reasonable-doubt standard, erroneous convictions are too often upheld. See Poulin, supra note 70, at 996 (noting that appellate courts had affirmed through written opinions the convictions of 133 of the first 200 defendants exonerated by DNA evidence, and that nearly a third of these opinions had noted error but concluded 
"beyond a reasonable doubt" test, if faithfully applied, simply invited too many reversals and thus risked a return to the days when appellate courts reversed indiscriminately. ${ }^{314}$ In contrast, he thought the second test sufficiently demanding and properly calibrated. ${ }^{315}$ Moreover, the second test could be administered without inevitably morphing into either a rule of near-automatic reversal or a rule of near-automatic affirmance in cases where there is strong evidence of guilt. ${ }^{316}$

In 2016, there is little reason for concern about appellate courts construing the Chapman principle as a rule calling for nearly automatic reversals. Harmless-error rulings are commonplace and in no way discouraged by the Supreme Court. ${ }^{317}$ The more pertinent question today is whether, if the Court were to discard the Chapman principle in favor of a "high probability" test grounded in $\S 2111$, would more errors be forgiven? I think not-especially if the Court were careful to explain its move as grounded not in a desire to decrease the rate at which appellate remedies are provided, but rather in a desire to clarify a badly muddled doctrine and to more accurately rationalize and describe the present realities of harmless-error review. For it is simply inaccurate to describe appellate practice today as one where courts tend to provide remedies unless they are nearly certain that the error played no role in the jury's decision to convict, as the Chapman principle purports to require. ${ }^{318}$

Indeed, the beyond-a-reasonable-doubt proof standard has always been inapt for use in connection with harmless-error review. The standard derives, of course, from the burden of proof that juries are instructed to apply in determining whether to return a guilty verdict and convict a criminal defendant of a crime. But before making such a finding, the jury is exposed to all of the admissible evidence that the government and the defendant wish it to see and hear about what actually happened. In other words, within the American criminal system, the finding

that it was harmless) (citing Brandon L. Garrett, Judging Innocence, 108 CoLUM. L. REV. $55,95,107-08$ (2008)).

314. See TRAYNOR, supra note 1, at 35-37, 43-44.

315. See id. at $44-45$.

316. See id. at 49-51.

317. See generally supra Parts II.B, II.C.

318. See supra notes 65-70 and accompanying text (describing the inconsistent ways in which the Court has operationalized Chapman); see also Poulin, supra note 70, at 1023-36 (exhaustively documenting the myriad ways-all inconsistent with a strict reading of Chapman-in which courts since Chapman have exercised their power to withhold remedies for constitutional error during the trial process on the ground that it did not cause "harm"). 
of guilt beyond a reasonable doubt is supposed to follow exposure to all admissible facts that reasonably might be thought to bear on that finding.

But reviewing courts are (quite sensibly) precluded from considering direct evidence about the jury's deliberations; they can only speculate about how a rational jury likely would have made use of the evidence with which it was presented. ${ }^{319}$ When the nature of the inquiry is inherently and necessarily hypothetical, why demand a conclusion-as Chapman doesunder a standard that purports to forswear doubt (or at least "reasonable" doubt) about its correctness? The conscientious judicial mind should almost always harbor doubt about conclusions reached not through evidence, but through hypothesis and conjecture. Thus, by its very nature, the Chapman principle requires a conclusion that the conscientious judge should balk at reaching. No wonder then that, as a practical matter, harmless-error analysis quickly moved away from a strict reading of Chapman and towards a more judicially administrable regime - one that the "high probability" standard more accurately describes as a matter of reality. ${ }^{320}$

In sum, the Court should stop privileging constitutional error and abandon Chapman in favor of a unitary harmless-error standard that does not ask judges to express near-certitude about a conclusion that by its very nature is somewhat doubtful. The Court should describe its new standard as an elaboration of 28 U.S.C. § 2111, the federal harmless-error statute. Finally, the Court should consider a clarifying reform-i.e., adoption of a "high probability" harmless-error test-that would more accurately rationalize and describe the rather highly qualified willingness of today's appellate courts to provide remedies for errors that occur during the process leading to criminal convictions.

\section{Abandoning Fulminante}

Again, the Constitution does not require a rule of automatic reversal in situations other than where an applicant for relief establishes the unconstitutionality of the statute of conviction, either facially or as-applied. ${ }^{321}$ That said, adherence to basic constitutional values and sound public policy require that convictions infected by certain types of error never be permitted

319. See FED. R. EvID. 606(b) (precluding post hoc inquiry into the nature of the jury's deliberations other than in rare circumstances).

320. See supra note 318 and accompanying text.

321. See supra note 190. 
to stand. Unfortunately, as Part II.B shows, the trial error/structural defect framework that the Supreme Court prescribed in Fulminante does a very poor job of drawing the line of demarcation between such errors and the default category of errors, to which harmless-error review applies. Fulminante permits instances of egregious government misconduct-e.g., the admission into evidence of a coerced confession ${ }^{322}$ - to go without a remedy. And if faithfully implemented (which it has not been), it also can require remedies for relatively inconsequential errors committed by government actors acting in good faith. ${ }^{323}$ The Court can do better than Fulminante in defining the class of errors that should not be subject to harmless-error review.

How might the Court pursue reform in this area? It might start by acknowledging that, regardless of their guilt, persons convicted of crimes who press claims of error on direct and collateral review serve as private attorneys general and, in that role, function as essential instruments for ensuring proper regard for fundamental constitutional criminal rules. ${ }^{324}$ In determining what constitutional criminal rules are so "fundamental" that their infraction always requires a remedy, we might start by noting the apparent agreement among all current Supreme Court Justices that the fair-trial guarantee always requires, at the very least, an impartial judge, a jury instruction that correctly states the relevant standard of proof, assistance of counsel for the accused, and a fair jury. ${ }^{325}$ Thus, errors undermining these foundational elements of the American criminal trial never should be subjected to harmless-error review.

322. See supra notes $76-77$ and accompanying text.

323. Cf. supra notes 242-253 and accompanying text (describing the Supreme Court's struggle, in Neder v. United States, 527 U.S. 1 (1999), to rationalize a harmless-error doctrine to govern in circumstances where the jury did not find an element of the offense but where no rational jury could have failed to make such a finding had it been properly instructed).

324. Harmless-error doctrine has been subjected to withering criticism over the years for failing to account for values other than the accuracy of criminal convictions-e.g., restraining human rights abuses and protecting the dignity of the accused-that constitutional criminal procedure rights are designed to protect. See, e.g., Sonja B. Starr, Sentence Reduction as a Remedy for Prosecutorial Misconduct, 97 GEO. L. J. 1509, 155455 (2009); Ogletree, supra note 15, at 161-72: Tom Stacy \& Kim Dayton, Rethinking Harmless Constitutional Error, 88 CoLUM. L. REV. 79, 88-89 (1988).

325. See United States v. Gonzalez-Lopez, 548 U.S. 140, 158 (2006) (describing elements of the trial structure whose deprivation necessarily renders a criminal trial fundamentally unfair or an unreliable vehicle for determining guilt or innocence) (citing Neder v. United States, 527 U.S. 1, 9 (1999)) (Alito, J., dissenting, joined by Roberts, C.J. \& Kennedy, J., and Thomas, J.). The Justices in the Gonzalez-Lopez majority appear to have a broader conception of the fair-trial guarantee and therefore likely would agree that it contains the elements specified in Justice Alito's dissent. 
For similar reasons, I submit, constitutional violations rooted in discrimination on the basis of race and other immutable characteristics always undermine fundamental values. ${ }^{326}$ Sensitivity to our ugly history of racism, sexism, and other forms of unconstitutional prejudice, and the grave harm their persistence inflicts on our institutions of justice, demand that nothing short of a zero-tolerance policy be applied when some agent of government violates the equal protection guarantee through invidious discrimination. ${ }^{327}$ Indeed, we might well consider going a step or two further and holding that intentional misconduct by a government actor of any sort undermines fundamental values and should automatically yield a remedy when demonstrated to the satisfaction of a reviewing court. In any event, the important point is that there is a glaring need to move beyond the Fulminante standard, which lacks practicality and therefore is not faithfully and predictably administered.

\section{Abandoning Brecht}

As Part II.C shows, the Supreme Court has engaged in a disingenuous treatment of precedent to create a harmless-error test to govern collateral review that will rarely yield a remedy. In order to establish that a constitutional trial error requires a new trial, habeas petitioners must satisfy a standard-supposedly rooted in Brecht/Kotteakos - that is in some unexplained way more demanding than the AEDPA/Chapman standard, which

326. In one context where claims of unlawful discrimination often arise-the use of peremptory challenges to jurors during the jury selection process (see, e.g., Batson v. Kentucky, 476 U.S. 79 (1986), where the Court held that unconstitutional race-based challenges and prescribing a process for resolving claims of error) - the federal appeals courts have unanimously concluded that a proven constitutional violation never can be harmless error. See, e.g., United States v. McAllister, 693 F.3d 572, 582 (6th Cir. 2012) (Batson error is structural and can never be harmless); Winston v. Boatwright, 649 F.3d 618, 632 (7th Cir. 2011) (same); Williams v. Woodford, 396 F.3d 1059, 1069 (9th Cir. 2005) (same); Tankleff v. Senkowski, 135 F.3d 235, 248 (2d Cir. 1998) (same); Ford v. Norris, 67 F.3d 162, 171 (8th Cir. 1995) (same); Ramseur v. Beyer, 983 F.2d 1215, 1225 n.6 (3d Cir. 1992) (same); United States v. Legrand, 483 Fed App’x 771, 777 n.2 (4th Cir. 2012) (unpublished opinion) (same); see also Vazquez v. Hillery, 474 U.S. 254, 260-64 (1986) (pre-Fulminante decision holding that racial discrimination in the grand jury process is not amenable to harmless-error review); United States v. Batchelder, 442 U.S. 114, 125 \& n.9 (1979) (pre-Fulminante decision holding that a criminal conviction is void if the prosecutor deliberately challenged the defendant because of his race).

327. Cf. Calhoun v. United States, 133 S. Ct. 1136, 1137-38 (2013) (statement of Justice Sotomayor, with whom Justice Breyer joined) (respecting the denial of the petition for a writ of certiorari the Court denounced in extremely strong terms an appeal to racial prejudice made by the federal prosecutor at trial, collected authority demonstrating that such appeals were once commonplace, and opined that "[s]uch conduct diminishes the dignity of our criminal justice system and undermines respect for the rule of law"). 
Brecht/Kotteakos is said to subsume. ${ }^{328}$ But even though the Brecht/Kotteakos standard is said to subsume the AEDPA/Chapman standard, and even though habeas courts are not required formally to apply both tests, Ayala makes clear that habeas courts will act at their peril if they skip over the AEDPA/Chapman test, and apply only the more demanding Brecht/Kotteakos test. ${ }^{329}$

In my view, the Court's test for assessing whether error was harmless on collateral review is far too forgiving. While Brecht may have been reasonable in making it more difficult for habeas petitioners who have demonstrated error to obtain a new trial, the AEDPA-enacted three years after Brecht-is more than adequate to address the concerns that animated Brecht. Under the AEDPA, habeas petitioners are unable to obtain relief without establishing clear error in light of Supreme Court precedent and that a state appellate court's harmlessness determination (if there was one) was itself unreasonable. ${ }^{330}$ These showings are far from easy to make, especially if the harmlessness determination were to be recast in the "high probability" terms for which I argue. In short, the "high probability" test ought to apply on both direct and collateral review.

Be that as it may, a majority of the Court apparently does not agree that the AEDPA is sufficiently strict. At the very least, however, the Court should come up with a regime less dismissive of rule-of-law values, and more judicially administrable, than that prescribed by Fry and Ayala. Perhaps the Court believes that habeas petitioners must show some likelihood of innocence. After all, the Constitution imposes no barrier to the imposition of such a standard. But if so, the Court should say so explicitly and forthrightly. For as matters now stand, the tests for determining whether an error should be excused as harmless on habeas are extraordinarily difficult to understand and administer.

\section{CONCLUSION}

Nearly half a century ago, Justice Traynor described then-nascent harmless-error doctrines as giving rise to a "riddle." Today, "quagmire" would be a more apt descriptor. The complex series of doctrines governing the provision of remedies responsive

328. See supra note 297 and accompanying text.

329. See supra notes 294-296 and accompanying text.

330. See supra notes 286-287 and accompanying text. 
to constitutional violations committed during the criminal trial process are badly in need of reform.

As we have seen, the path to reform is almost entirely unobstructed by constitutional limitations. Hopefully, the Supreme Court will come to agree that a housecleaning is needed, and will consider steps aimed at making harmless-error review more realistic, more consistent across contexts, and more transparent about its animating values. The Court could start this process by adopting a unitary harmless-error test to govern all error, abandoning the unrealistic trial error/structural defect framework for assessing whether errors can be excused, and simplifying and clarifying its approach to harmless-error review on collateral review. 